Review

\title{
Non-Coding RNAs and Wnt/ $\beta$-Catenin Signaling Pathway in Gastric Cancer: From EMT to Drug Resistance
}

\author{
Bruno Takao Real Karia ${ }^{1,+} \oplus$, Camila Albuquerque Pinto ${ }^{1,+}\left(\mathbb{D}\right.$, Carolina Oliveira Gigek ${ }^{2}$, Fernanda Wisnieski ${ }^{1,3}$ \\ and Marilia Arruda Cardoso Smith $1, *$ (1) \\ 1 Disciplina de Genética, Departamento de Morfologia e Genética, Universidade Federal de São Paulo, \\ São Paulo 04023-900, Brazil; brunokaria@gmail.com (B.T.R.K.); camila.pinto@unifesp.br (C.A.P.); \\ f.wisnieski@unifesp.br (F.W.) \\ 2 Departamento de Patologia, Universidade Federal de São Paulo, São Paulo 04023-062, Brazil; \\ carolina.gigek@unifesp.br \\ 3 Disciplina de Gastroenterologia, Departamento de Medicina, Universidade Federal de São Paulo, \\ São Paulo 04023-062, Brazil \\ * Correspondence: macsmith@unifesp.br \\ + These authors contributed equally to this work.
}

check for updates

Citation: Takao Real Karia, B.; Albuquerque Pinto, C.; Gigek, C.O.; Wisnieski, F.; Arruda Cardoso Smith, M. Non-Coding RNAs and Wnt/ $\beta$-Catenin Signaling Pathway in Gastric Cancer: From EMT to Drug Resistance. Onco 2021, 1, 140-157. https://doi.org/10.3390/onco1020012

Academic Editors: Fred Saad and Danny N. Dhanasekaran

Received: 12 October 2021

Accepted: 23 November 2021

Published: 25 November 2021

Publisher's Note: MDPI stays neutral with regard to jurisdictional claims in published maps and institutional affiliations.

Copyright: (c) 2021 by the authors. Licensee MDPI, Basel, Switzerland. This article is an open access article distributed under the terms and conditions of the Creative Commons Attribution (CC BY) license (https:// creativecommons.org/licenses/by/ $4.0 /)$.
Simple Summary: Gastric cancer is one of the leading causes of cancer-related death worldwide. Although the treatment of gastric cancer patients has improved during the last decades, survival rates are still around $20 \%$. Non-coding RNAs were shown to participate in numerous pathways during the development and progression of gastric cancer. MicroRNAs and lncRNAs are among the most well studied classes of non-coding RNAs, since they have important roles as oncogenic or tumor suppressor molecules in several pathways. The Wnt/ $\beta$-catenin signaling pathway was proven to be critical in different contexts in cell biology and may help in prognosis and diagnosis of gastric cancer.

Abstract: Gastric cancer is one of the most common cancers and the third cause of cancer-related death worldwide. The treatment of GC patients improved due to advancements in surgery, radiotherapy and chemotherapy. However, the long-term survival rate of patients with gastric cancer remains around $20 \%$. Thus, development of novel therapeutic approaches is of great interest, in order to reduce the need for mutilating surgeries and morbid adjuvant therapies. For many years, it was believed that the RNA was a mere intermediate molecule in the genetic information flow. However, during the past decades, with the advent of new sequencing technologies, it was revealed that non-coding RNAs play important roles in many different biological processes. The Wnt/ $\beta$-catenin signaling pathway has been reported to regulate crucial events during neoplasic development, such as cell differentiation, proliferation, invasion, migration, apoptosis, and angiogenesis. In this review, we will focus on microRNAs and long non-coding RNAs that have been implicated in gastric cancer tumorigenesis via modulation of the Wnt/ $\beta$-catenin signaling pathway, which provided some biomarkers to prognosis, diagnosis, and therapy.

Keywords: non-coding RNAs; lncRNAs; microRNAs; Wnt pathway; gastric cancer

\section{Introduction \\ 1.1. Gastric Cancer}

Gastric cancer (GC) is the fifth most common cancer and the third cause of death caused by cancer worldwide, with over 1,000,000 new cases per year and more than 700,000 deaths. Generally, this type of neoplasm affects men more frequently than women, with incidence rates being around two-fold higher in males compared to females. GC incidence rates are prominently increased in Eastern Asia, where the average incidence is 32.1 per 100,000 among males and 13.2 per 100,000 among females. South America (12.7 per 
100,000 among men and 6.9 per 100,000 among women) and Eastern Europe (17.1 per 100,000 for males and 7.5 per 100,000 for females) are also regions where GC incidence is very high [1]. The risk factors associated with GC include infection by microorganisms, such as Helicobacter pylori and Epstein-Barr virus, and lifestyle habits, including high consumption of alcohol and smoking, increased intake of foods preserved by salting, and low fruit ingestion [2-5].

More than $90 \%$ of gastric tumors originate from the gastric glands on the stomach mucosa, and therefore are called adenocarcinomas. These tumors are commonly classified into subgroups based on different parameters. Anatomically, the stomach can be classified into cardia (the portion closest to the esophagus), fundus (the upper part), body (the main part), antrum (the lower portion), and pylorus (furthest part). Accordingly, the GC adenocarcinomas may be divided into cardia or non-cardia [6]. Moreover, some studies have proposed that these two subtypes may have distinct etiologies [7]. These tumors can also be categorized into intestinal or diffused, according to histological subtypes [8]. The intestinal type is more incident, with males being more affected than females (roughly twofold). In addition, these patients usually have a well-differentiated tumor and, consequently, a better prognosis. On the other hand, the diffused type is less frequent; however, its incidence rate has been increasing by $3.6 \%$ per year, on average. Additionally, this type is characterized as less differentiated, and the patients have a worse prognosis $[9,10]$. New and molecular approaches have been described in an attempt to propose a comprehensive classification, as previously reviewed by our group [11].

In general, GC is diagnosed late due to the fact the patients are usually asymptomatic or present nonspecific symptoms for a long period of time. Consequently, these tumors often metastasize by the time of diagnosis, which contributes to the poor prognosis of the disease. During the past years, the treatment of GC patients has improved thanks to advancements in surgery, radiotherapy, and chemotherapy. However, this was not translated into better long-term survival rates, since the five-year overall survival rate is around $20 \%$ [6]. In this context, various researchers have been working on identifying molecular targets for diagnosis and prognosis of GC, as well as for developing novel therapeutic approaches to reduce the need for mutilating surgeries and morbid adjuvant therapies.

\subsection{Non-Coding RNAs}

For many years, molecular biologists believed that the primary function of the RNA was to encode sequence information. The few exceptions were components of protein containing complexes, such as ribosomal RNA (rRNA) and telomerase RNA component (TERC) [1,2]. However, modern sequencing technologies revealed that the majority of the human transcriptome is composed of non-coding RNAs (ncRNAs) [12-14]. Moreover, these molecules have been described as critical for a range of functions in various cellular processes, such as cell cycle, development, and metabolism, for instance $[15,16]$. Depending of the size of the molecule, ncRNAs may be divided into long non-coding RNAs (lncRNAs), if the transcript contains more than 200 nucleotides; or small ncRNAs, when they are shorter than 200 nucleotides [17]. Small ncRNAs may also be further divided into different categories, such as piwi-interacting RNA (piRNAs), small nuclear RNA (snRNAs), small nucleolar RNAs (snoRNAs), and microRNAs (miRNAs), among others [18] (Figure 1).

Here, we will emphasize the roles of lncRNAs and microRNAs that regulate gastric tumorigenesis through the Wnt/ $\beta$-Catenin pathway.

\subsection{Long Non-Coding RNAs}

As previously mentioned, the ncRNAs that contain more than 200 nucleotides in length are named long non-coding RNAs [17]. As well as miRNAs, lncRNAs are also frequently polyadenylated and transcribed by RNA Pol II [19]. In addition, many lncRNA transcripts are spliced and capped [20], conferring to them the ability to survive longer periods of time in the cell nucleus. Thus, differently from miRNAs, which act in the 
cytoplasm of the cells, where they either degrade mRNA or repress its expression, lncRNAs were shown to have a wide variety of functions (Figure 2).

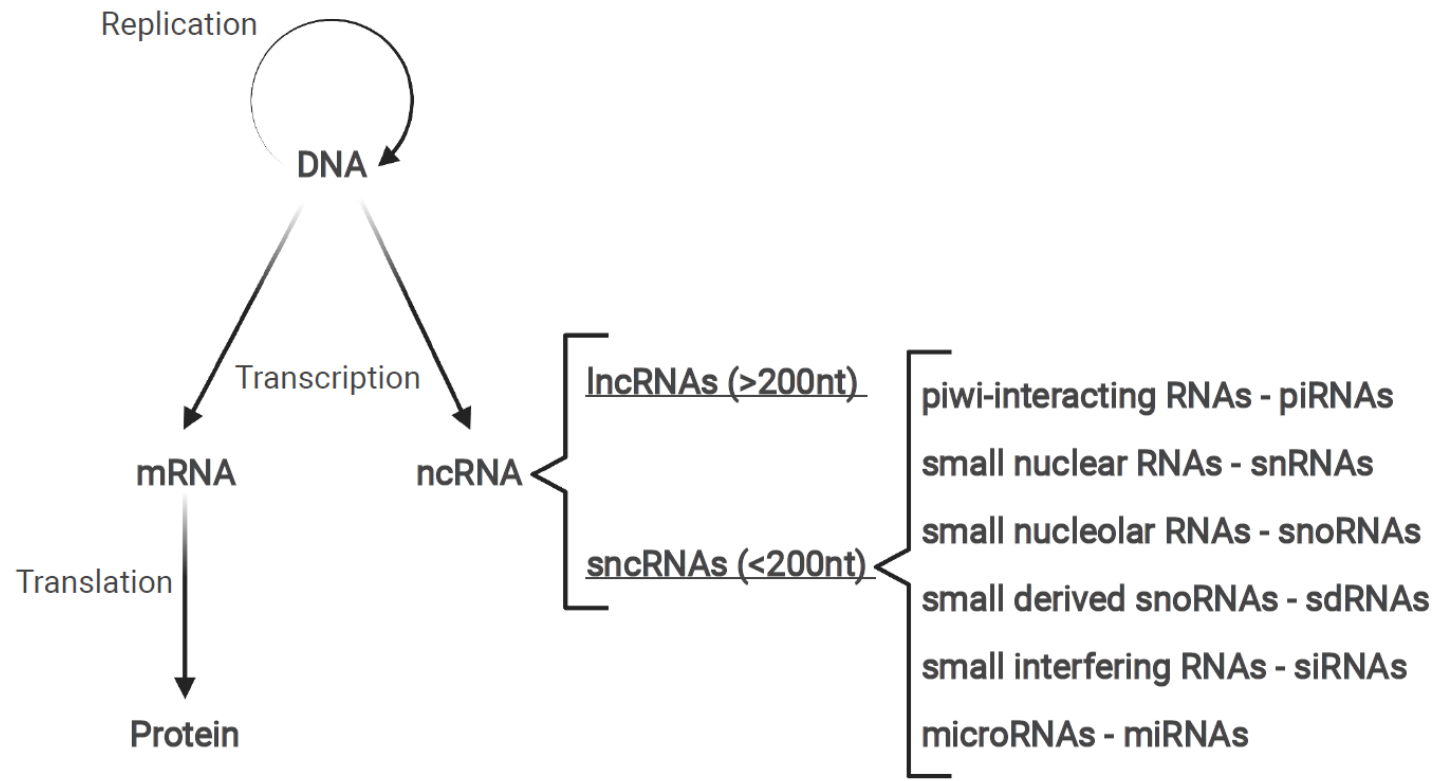

Figure 1. The different subclasses of non-coding RNAs. Ribosomal RNA (rRNA) and transfer RNA (tRNA) are the most abundant and known ncRNAs. Long non-coding RNAs (lncRNA) are longer than 200 nt. Short non-coding RNAs (short ncRNAs) are smaller than $200 \mathrm{nt}$ and may be subcategorized based on their size and function: siRNA (small interfering RNA), miRNA (microRNA), piRNA (PIWI-interacting RNA), snoRNA (small nucleolar RNA), and derived snoRNA (sdRNA).

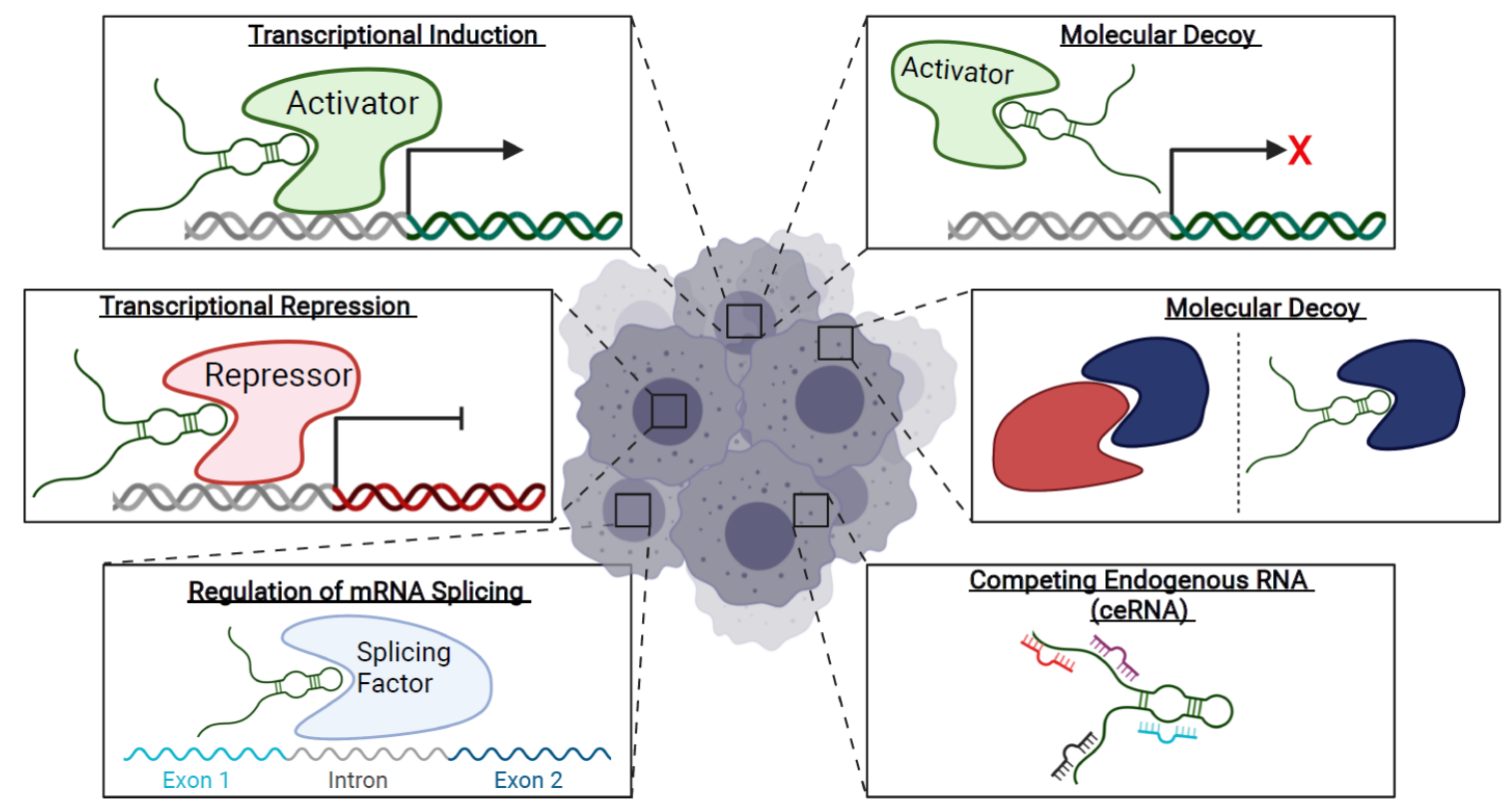

Figure 2. The functions of lncRNAs. LncRNAs have a diverse range of functions depending on their subcellular localization. Nuclear lncRNAs may work as transcriptional inductors, by interacting with transcriptional activators, causing target gene activation; transcriptional repressors, by interacting with transcriptional repressors, preventing target gene activation; regulators of mRNA splicing, by interacting with splicing factors; and molecular decoys, keeping transcriptional activators away from chromatin. Cytoplasmic lncRNAs, among other functions, frequently act as molecular decoys, preventing protein-protein interactions, and competing endogenous RNAs, serving as molecular sponges titrating miRNAs away from their mRNA targets. 
Usually, nuclear lncRNAs act as regulators of gene expression. In this case, a given lncRNA interacts with and recruits transcription activators or repressors to gene promoters. Moreover, this type of regulation can occur in cis, when the lncRNA activates or represses genes near their own site of transcription. Alternatively, lncRNAs may influence the expression in trans, when they influence the expression of a distant gene.

An example of cis-acting lncRNA is APTR (Alu-mediated p21 Transcription Regulator), a lncRNA transcribed from chromosome 7q21, which recruits the Polycomb repressive complex 2 (PRC2) to the p21 gene promoter (localized in chromosome 6p21.2), repressing its expression [21]. Another function of lncRNAs localized to the nucleus is to function as molecular decoys. PANDA (p21 Associated ncRNA DNA Damage Activated) sequesters the transcription factor NF-YA (Nuclear transcription factor Y subunit alpha) and prevents the activation of the target genes CCNB1 (Cyclin B1), FAS (Fas Cell Surface Death Receptor), BBC3 (BCL2 Binding Component 3), and PMAIP1 (Phorbol-12-Myristate-13Acetate-Induced Protein 1) [22].

The most frequent function of cytoplasmic lncRNAs is working as competing endogenous RNAs (ceRNAs).

Many examples have been reported over the years, including LINC00689 (Long Intergenic Non-Protein Coding RNA 689), which sponges miR-526b-3p, preventing it from binding and degrading ADAM9 (ADAM Metallopeptidase Domain 9) [23]. Cytoplasmic lncRNAs also may regulate mRNA and protein stability [24] and be molecular decoys for proteins or RNAs [25].

Until this moment, 172,216 human lncRNA transcripts and 96,308 lncRNA genes have been identified [26]; the number is larger than the 84,485 protein-coding transcripts and 19,954 protein-coding genes [27]. Additionally, although they are less conserved and expressed in lower levels than protein-coding genes $[19,20,28]$, as pointed out previously, many groups have shown their importance for various physiological and pathological processes.

\subsection{MicroRNAs}

MiRNAs comprehend a class of endogenous sncRNAs (small non-coding RNA) that range from 17 to $27 \mathrm{nt}$ in size ( 22 nt) and are expressed both in plants and animals [29]. They regulate gene expression post-transcriptionally by base pairing with mRNAs of protein-coding genes to repress their expression. Mechanistically, a miRNA can either cleave or repress an mRNA, depending on how precise the base complementarity is with the mRNA. A miRNA-mRNA perfect base pairing will result in the degradation of the mRNA, while an imperfect base pairing will cause the repression of the mRNA, inhibiting protein translation. Furthermore, the base pairing of nucleotides 2 to 7 was shown to be crucial for the recognition of the miRNA with the target mRNA; this region is referred to as the seed sequence [30].

In the nucleus of mammalian cells, miRNAs genes are usually transcribed by RNA polymerase II (Pol II) into a long capped, polyadenylated, and spliced primary microRNA (pri-miRNA) molecule. Subsequently, pri-miRNAs are cleaved into a hairpin-shaped precursor microRNA (pre-miRNA) by the microprocessor complex, which is composed of DGCR8 (DiGeorge Syndrome Critical Region 8) and DROSHA (Drosha Ribonuclease III). Successively, the pre-miRNA hairpin is exported from the nucleus by Exportin 5 (XPO5) to the cytoplasm, where it is processed by the RNase III endonuclease DICER, resulting in the mature miRNA duplex [29]. Therefore, one pre-miRNA molecule yields two mature single-strand miRNAs. The $5^{\prime}$-end of the pre-miRNA originates the $5 p$ strand, whereas the $3 p$ strand derives from the $3^{\prime}$-end [31]. Thereafter, the mature miRNA associates with the Argonaute protein (AGO), one of the components of the RNA-induced silencing complex (RISC), where it will negatively regulate mRNA expression [29] (Figure 3). 


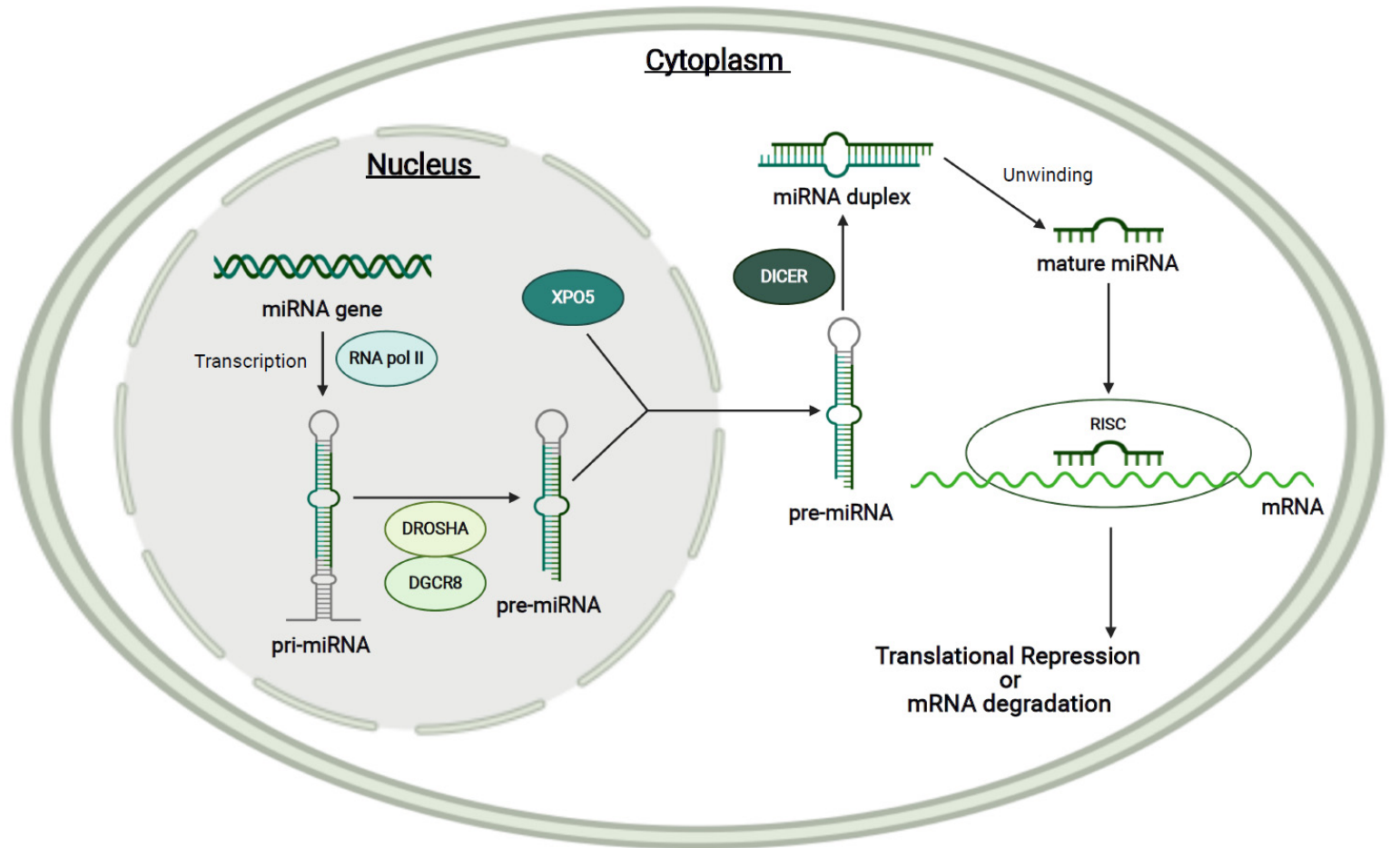

Figure 3. Schematic representation of miRNA biogenesis. In the cell nucleus, miRNA genes are transcribed by RNA polymerase II (RNA pol II) into primary microRNAs, or pri-miRNAs. Then, these hairpin molecules are processed by Drosha into precursor microRNAs or pre-miRNAs. After exportation to the cytoplasm by Exportin 5 (XPO5), Dicer processes these molecules into miRNA duplexes. Mature miRNAs can recognize seed sequences in the $3^{\prime}$ UTRs of target mRNAs and repress gene expression by either destabilizing target mRNAs or repressing their translation.

Since the identification of the first discovered miRNA, lin-4 [32], 2656 other human mature miRNAs have been identified with more than 29,000 unique gene targets [33]. Many of them have been reported to be relevant in the context of disease, including cancer, such as let-7 and miRNA-106b-5p [34,35]. In this review, we will emphasize the ones involved in gastric cancer and the Wnt/ $\beta$-catenin signaling pathway.

\subsection{Wht/ $\beta$-Catenin Pathway}

The Wnt signaling pathways are one of the most important and well-studied group of signal transduction pathways in cell biology. They have been reported to regulate crucial events during embryonic development, such as cell differentiation, polarization, and migration [36,37]. In addition, dysregulations on these pathways have been reported to implicate in pathological conditions, as type 2 diabetes mellitus and cancer [38,39].

To date, three different pathways have been described. The Wnt/ $\beta$-catenin pathway (canonical) relies on the translocation of $\beta$-catenin to the nucleus where it mainly acts as a coactivator for the TCF/LEF (T-cell specific transcription factor/lymphoid enhancer binding factor) transcriptional factor family. The other two pathways are independent of $\beta$-catenin and are referred to as non-canonical [40].

The non-canonical planar cell polarity pathway, among others, regulates cell polarity (asymmetric distribution of molecular components within the cell) during embryonic development [41].

The non-canonical Wnt/calcium pathway is responsible for regulating the intracellular calcium levels.

The canonical or Wnt/ $\beta$-Catenin pathway, as previously stated, results in transcription factor activation as a consequence of $\beta$-catenin translocation to the nucleus. In the absence of Wnt, cytosolic $\beta$-catenin is constantly degraded by a destruction complex formed by Axin, APC (Adenomatous polyposis coli), PP2A (protein phosphatase 2A), CK1 (Casein 
kinase 1), and GSK3 (glycogen synthase kinase 3 ). This complex phosphorylates $\beta$-catenin and $\beta$-TrCP (Beta-Transducin Repeat Containing E3 Ubiquitin Protein Ligase) recognizes and ubiquitin tags it to proteasome degradation. However, when extracellular Wnt binds to Frizzled, the receptor, and the co-receptor LRP5/6 (lipoprotein receptor-related protein 5/6), disheveled protein is recruited, and LRP5/6 becomes phosphorylated. Axin is then translocated to the plasma membrane, disrupting the Axin-mediated phosphorylation/degradation of $\beta$-catenin. Finally, $\beta$-catenin accumulates in the cytoplasm and translocates to the nucleus where it serves as a co-activator for the TCF transcription factor family to activate Wnt responsive genes [40].

The canonical Wnt pathway is considered crucial to important processes, including wounds and healing, embryonic development, cell proliferation, and EMT (epithelial to mesenchymal transition) [42-44]. Moreover, the dysregulation of the Wnt/ $\beta$-Catenin pathway induces tumor progression in different tissues [45-48], including the stomach. In fact, components of the Wnt signaling pathway were shown to be dysregulated in GC tissue samples. Genomic analysis identified that $46 \%$ of gastric tumors exhibit deregulation of the Wnt/ $\beta$-catenin pathway. Additionally, several Wnt ligands are upregulated in human gastric tumors, including WNT1, WNT2b, WNT5a, WNT6, and WNT10a [49]. In addition, many reports indicate that the components and the target genes of this signaling pathway are upregulated and mutated, both in humans and animal models [50-55]. Finally, there are studies reporting that in GC, $\beta$-catenin translocates to the nucleus of GC cells, further indicating that the Wnt/ $\beta$-catenin pathway is important in this context $[56,57]$. Thus, in this review, we will discuss the role of miRNAs and lncRNAs in the Wnt/ $\beta$-Catenin pathway and their importance to gastric tumorigenesis (Figure 4).

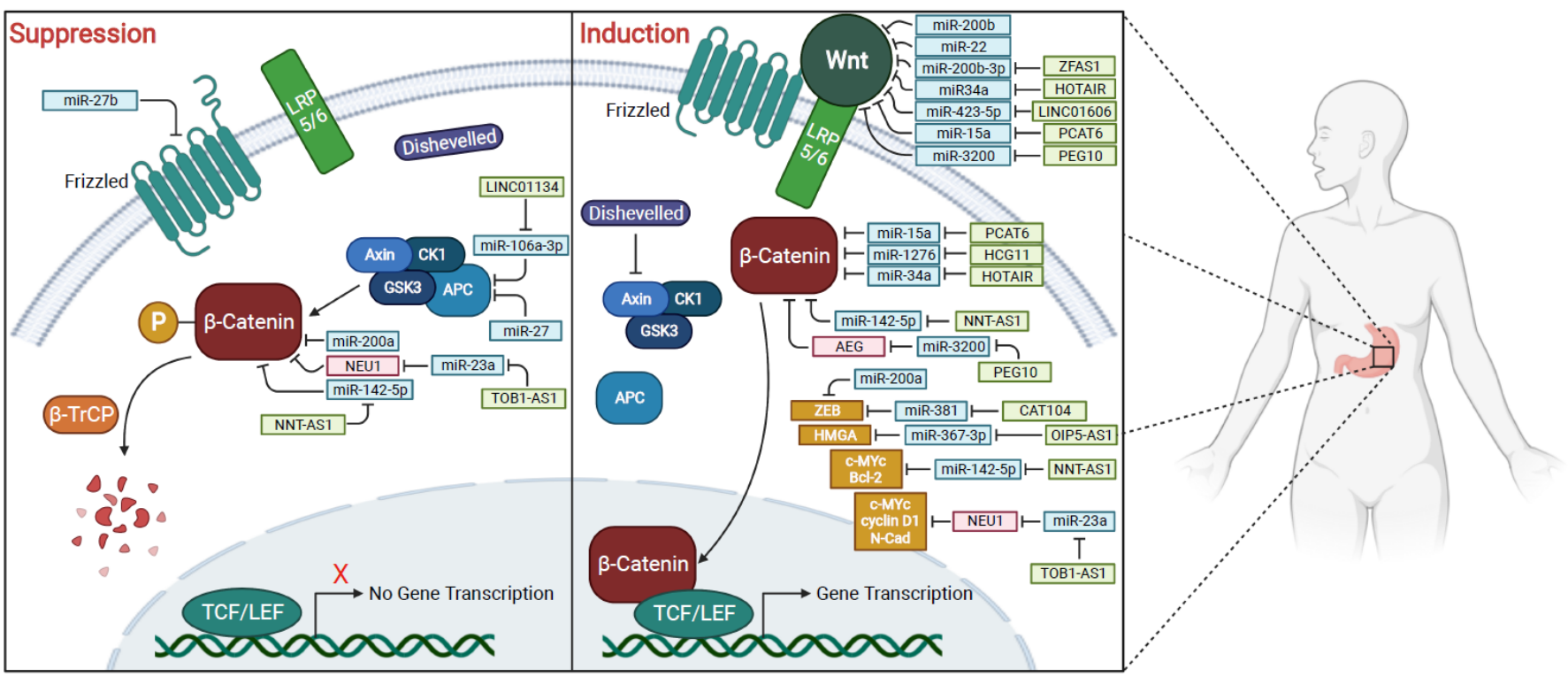

Figure 4. Schematic representation of the regulatory functions of oncogenic and tumor suppressor ncRNAs on canonical Wnt signaling pathways in gastric cancer cells.

\section{MicroRNAs Associated with Wnt/ $\beta$-Catenin Signaling Pathway}

In the following sections, we will describe in more detail the most prominent Wnt/ $\beta$ catenin-related miRNAs in GC. However, the summary of all GC miRNAs involved in the Wnt/ $\beta$-catenin may be found in Tables 1-4.

\subsection{Epithelial-to-Mesenchymal Transition (EMT) and Metastasis Increase in Gastric Cancer}

During embryogenesis, through a series of cell divisions and transformations, a singlecell organism gives rise to a complex multicellular organism. During this process, some epithelial cells change their configurations to acquire some mesenchymal cell features. The 
loss of epithelial characteristics and gain of mesenchymal features is called epithelial-tomesenchymal transition (EMT).

EMT is a multistage and reversible process related to cellular adhesion and communication, and it is part of natural processes, such as embryogenesis and wound healing. Besides that, EMT may occur in some pathological changes, such as cancer, specifically in metastasis initiation. This process comprehends several stages, which includes changes in apical-basal polarity organization of epithelial cells and changes in cells arrangement, determined by activation of EMT transcription factors, which is then followed by induced expression of genes related to mesenchymal state. Such alterations can give a huge advantage in mobility and invasive capacities, improving metastasis and elevating resistance to many cancer therapies [58].

In this setting, the Wnt/ $\beta$-catenin signaling pathway plays an important role in the activation of EMT process. In addition, it has been shown that miRNAs can induce or suppress Wnt/ $\beta$-catenin signaling, as they can act as oncogenes (OncomiRNAs) or as tumor suppressors [59]. Therefore, in this topic, the studies were grouped into two different tables, according to miRNAs effects in Wnt/ $\beta$-catenin signaling and stimulating or suppressing the EMT process (Tables 1 and 2).

Overexpressing or silencing gene assays using siRNAs in cell culture are commonly used to explore the capacity of cell proliferation, migration, and invasion before and after transfection. Possible miRNA target genes are observed in different target prediction tools.

Table 1 shows the miRNAs involved in promoting EMT in GC, describing their targets, their major molecular effects, the study type (in vitro, in vivo, or both), and the consequences on Wnt / $\beta$-catenin pathway and on EMT. Noticeably, miR-27 is upregulated in gastric cancer and it targets the APC gene to stimulate the Wnt/ $\beta$-catenin pathway [60].

Table 1. OncomiRNAs associated with Wnt/ $\beta$-catenin pathway and their roles to the epithelial-to-mesenchymal transition (EMT) progress in gastric cancer.

\begin{tabular}{|c|c|c|c|c|c|c|}
\hline OncomiRNAs & Targets & $\begin{array}{c}\text { Consequence on } \\
\text { Wnt } / \beta \text {-Catenin Pathway }\end{array}$ & $\begin{array}{l}\text { Consequence } \\
\text { on EMT }\end{array}$ & Major Effects & Study Type & Ref. \\
\hline $\operatorname{miR}-27$ & APC & Induction & Induction & $\begin{array}{c}\uparrow Z E B 1, \text { ZEB2, Slug, Vimentin } \\
\downarrow \text { E-cadherin }\end{array}$ & In vitro & {$[60]$} \\
\hline miR-199a-5p & E-cadherin & Induction & Induction & $\begin{array}{l}\downarrow \text { E-cadherin levels under } \\
\text { SRF action }\end{array}$ & $\begin{array}{l}\text { In vitro and } \\
\text { in vivo }\end{array}$ & [61] \\
\hline miR-194 & SUFU & Induction & Induction & $\uparrow \beta$-catenin & $\begin{array}{l}\text { In vitro and } \\
\text { in vivo }\end{array}$ & [62] \\
\hline miR-192 & SMG-1 & Induction & Induction & $\begin{array}{l}\downarrow \text { SMG } \downarrow \text { E-cadherin, } \\
\uparrow N \text {-cadherin }\end{array}$ & $\begin{array}{l}\text { In vitro and } \\
\text { in vivo }\end{array}$ & [63] \\
\hline $\operatorname{miR}-215$ & SMG-1 & Induction & Induction & $\begin{array}{c}\downarrow S M G \downarrow E \text {-cadherin } \\
\uparrow N \text {-cadherin }\end{array}$ & $\begin{array}{l}\text { In vitro and } \\
\text { in vivo }\end{array}$ & [63] \\
\hline miR-188-5p & PTEN & Induction & Induction & $\begin{array}{c}\uparrow \text { Phospho-Ser9 of GSK3 } \beta ; \\
\uparrow W n t\end{array}$ & $\begin{array}{l}\text { In vitro and } \\
\text { in vivo }\end{array}$ & [64] \\
\hline $\operatorname{miR}-675$ & PITX1 & Induction & Induction & $\begin{array}{c}\uparrow \text { Cell proliferation, } \\
\text { migration and invasion }\end{array}$ & In vitro & [65] \\
\hline
\end{tabular}

$\uparrow$ : Upregulation, $\downarrow$ : Downregulation.

Levels of E-cadherin and $\mathrm{N}$-cadherin were measured to evaluate the suppression or induction of EMT. In the same way, proteins related to Wnt/ $\beta$-catenin signaling were analyzed to classify the effects of miRNAs in this signaling pathway. Generally, EMT starts when the Wnt/ $\beta$-catenin pathway is hyperstimulated by OncomiRNAs, and the opposite occurs when Wnt/ $\beta$-catenin pathway is repressed by tumor suppressor miRNAs.

Similarly, Table 2 presents the miRNAs that suppress EMT in GC. It also states the miRNA targets, their major molecular effects, the study type (in vitro, in vivo, or both), and the consequences for the Wnt/ $\beta$-catenin pathway and for EMT. 
Table 2. Tumor suppressor miRNAs associated with Wnt/ $\beta$-catenin pathway and their roles in epithelial-to-mesenchymal transition (EMT) progress in gastric cancer.

\begin{tabular}{|c|c|c|c|c|c|c|}
\hline $\begin{array}{c}\text { Tumor Suppressor } \\
\text { miRNAs }\end{array}$ & Targets & $\begin{array}{c}\text { Consequence for } \\
\text { Wnt } / \beta \text {-Catenin Pathway }\end{array}$ & $\begin{array}{l}\text { Consequence } \\
\text { for EMT }\end{array}$ & Major Effects & Study Type & Ref. \\
\hline miR-200a & $\begin{array}{c}\text { ZEB1, } \\
\text { ZEB2 and } \\
\beta \text {-catenin }\end{array}$ & Suppression & Suppression & $\begin{array}{c}\downarrow N \text {-cadherin } \\
\downarrow \beta \text {-catenin } \\
\uparrow \text { E-cadherin } \\
\downarrow \text { KIAA1199 }\end{array}$ & $\begin{array}{l}\text { In vitro and } \\
\text { in vivo }\end{array}$ & {$[66,67]$} \\
\hline $\operatorname{miR}-29 c-3 p$ & KIAA1199 & Suppression & Suppression & $\begin{array}{c}\downarrow N \text {-cadherin } \\
\uparrow \mathrm{E} \text {-cadherin } \\
\uparrow \text { Axin2 }\end{array}$ & $\begin{array}{l}\text { In vitro and } \\
\text { in vivo }\end{array}$ & {$[68]$} \\
\hline $\operatorname{miR}-381$ & CUL4B & Suppression & Suppression & $\begin{array}{l}\downarrow \text { Cell proliferation } \\
\text { and invasion }\end{array}$ & $\begin{array}{l}\text { In vitro and } \\
\text { in vivo }\end{array}$ & [69] \\
\hline $\operatorname{miR}-489$ & CUL4B & Suppression & Suppression & $\begin{array}{l}\downarrow \text { Cell proliferation and } \\
\text { invasion }\end{array}$ & $\begin{array}{l}\text { In vitro and } \\
\text { in vivo }\end{array}$ & [69] \\
\hline $\operatorname{miR}-338$ & EphA2 & Suppression & Suppression & $\downarrow$ EMT-related markers & In vitro & [70] \\
\hline $\operatorname{miR}-375-3 p$ & YWHAZ & Suppression & Suppression & $\begin{array}{c}\downarrow \text { Cell proliferation and } \\
\text { invasion }\end{array}$ & In vitro & [71] \\
\hline $\operatorname{miR}-338-3 p$ & SOX5 & Suppression & Suppression & $\downarrow$ Cell proliferation & $\begin{array}{l}\text { In vitro and } \\
\text { tissues. }\end{array}$ & [72] \\
\hline $\mathrm{miR}-873$ & STRA6 & Suppression & Suppression & $\begin{array}{c}\downarrow \text { Cell migration and } \\
\text { invasion }\end{array}$ & $\begin{array}{l}\text { In vitro and } \\
\text { in vivo }\end{array}$ & [73] \\
\hline
\end{tabular}

$\uparrow$ : Upregulation, $\downarrow$ : Downregulation.

Thus, as exhibited in Table 2, most reports showed that miRNAs that suppress the Wnt/ $\beta$-catenin pathway also suppress the EMT process, differing only by the genes they target. Thereby, some studies explored miR-200a functions, and its target genes, such as the $\beta$-catenin gene (CTNNB1) [66], ZEB1 (Zinc finger E-box-binding homeobox 1) and ZEB2 (Zinc finger E-box-binding homeobox 2), E-cadherin repressors, under the influence of Toosendanin, a bioactive compound extracted from Melia Fructus [74]. Lina and colleagues bring to the discussion a gene included in the human unidentified gene-encoded (HUGE), KIAA1199 (Hyaluronan-Binding Protein Involved In Hyaluronan Depolymerization). This gene is related to non-syndromic hearing loss and most recently related to the gain of characteristics related to the EMT process in cancer cells. In that research, they showed the effect of KIAA1199 in gastric cancer as a stimulated factor of metastasis by binding to WBP11 (WW Domain Binding Protein 11) and PTP4A3 (Protein Tyrosine Phosphatase 4A3) and regulating the EMT-related Wnt and EGFR signaling pathways. Functional assays showed that KIAA1199 is a target gene of miR-29c-3p and can be altered in vitro and in vivo by overexpression and knockout of miR-29c-3p [68].

\subsection{Cell Proliferation, Migration, Invasion, and Apoptosis}

Some studies explore the functions of miRNAs and their relationship with some cell phenotypes, such as cell proliferation, migration, and invasiveness, as we can see in Table 3. Most of studies showed miRNAs related to decreased cell proliferation and decreased tumor growth. Just a small part of the studies explored miRNAs with oncogenic potential in gastric cancer.

Qiu et al. studied TRIM29 (Tripartite motif containing 29) and miR-185. The results indicated that TRIM29 acted as an oncogene in GC, improving cell cycle progression and decreasing apoptosis. MiR-185 was reported to be downregulated in GC and to target TRIM29, acting as a tumor-suppressive gene in GC. Interestingly, miR-185 overexpression inhibited cell proliferation and colony formation and induced apoptosis. In addition, the upregulation of miR-185 caused a decrease in the Wnt/ $\beta$-catenin pathway genes $\beta$-catenin, c-myc, and cyclinD1 [79]. 
Table 3. MiRNAs associated with cell proliferation, migration, invasion, and apoptosis phenotypes and Wnt/ $\beta$-catenin pathway in gastric cancer.

\begin{tabular}{|c|c|c|c|c|c|c|c|c|c|}
\hline miRNAs & $\begin{array}{l}\text { Status } \\
\text { in GC }\end{array}$ & Targets & $\begin{array}{l}\text { Consequence on Wnt/ } \beta \text { - } \\
\text { Catenin Pathway }\end{array}$ & $\begin{array}{l}\text { Cell Prolif- } \\
\text { eration }\end{array}$ & $\begin{array}{l}\text { Cell Migration } \\
\text { and Invasion }\end{array}$ & Apoptosis & $\begin{array}{l}\text { Tumor } \\
\text { Growth }\end{array}$ & Study Type & Ref. \\
\hline miR-200b & $\downarrow$ & Wnt-1 & Suppression & $\downarrow$ & - & - & $\downarrow$ & $\begin{array}{l}\text { In vitro and } \\
\text { in vivo }\end{array}$ & [75] \\
\hline miR-22 & $\downarrow$ & Wnt-1 & Suppression & $\downarrow$ & - & - & $\downarrow$ & $\begin{array}{l}\text { In vitro and } \\
\text { in vivo }\end{array}$ & {$[75]$} \\
\hline miR-19 & $\downarrow$ & MEF2D & Suppression & $\downarrow$ & - & - & $\downarrow$ & $\begin{array}{l}\text { In vitro and } \\
\text { in vivo }\end{array}$ & [76] \\
\hline $\operatorname{miR}-27 \mathrm{~b}$ & $\downarrow$ & FZD7 & Suppression & $\downarrow$ & - & - & - & In vitro & [77] \\
\hline miR-511 & $\downarrow$ & TRIM24 & Suppression & $\downarrow$ & $\downarrow$ & - & - & In vitro & [78] \\
\hline miR-185 & $\downarrow$ & TRIM29 & Suppression & $\downarrow$ & - & - & - & In vitro & [79] \\
\hline miR-532 & ${ }_{\uparrow}^{r}$ & NKD1 & Induction & ${ }^{*}$ & $\uparrow$ & - & - & In vitro & [80] \\
\hline miR-324-3p & $\uparrow$ & Smad4 & Induction & $\uparrow$ & $\uparrow$ & - & $\uparrow$ & $\begin{array}{l}\text { In vivo, In vitro } \\
\text { and organoids }\end{array}$ & [81] \\
\hline miR-195-5p & $\downarrow$ & Not elucidated & Suppression & $\downarrow$ & - & $\uparrow$ & - & $\begin{array}{l}\text { In vitro and } \\
\text { samples }\end{array}$ & [82] \\
\hline miR-18a & $\uparrow$ & SMAD2 & Induction & $\uparrow$ & $\uparrow$ & - & - & $\begin{array}{l}\text { In vitro and } \\
\text { in vivo }\end{array}$ & [83] \\
\hline miR-19a & $\uparrow$ & SMAD2 & Induction & $\uparrow$ & $\uparrow$ & - & - & $\begin{array}{l}\text { In vitro and } \\
\text { in vivo }\end{array}$ & [83] \\
\hline miR-876-5p & $\downarrow$ & $\begin{array}{l}\text { WNT5A and } \\
\text { MITF }\end{array}$ & Suppression & $\downarrow$ & $\downarrow$ & $\uparrow$ & $\downarrow$ & $\begin{array}{l}\text { In vitro and } \\
\text { in vivo }\end{array}$ & [84] \\
\hline
\end{tabular}

$\uparrow$ : Upregulation, $\downarrow$ : Downregulation.

Some studies use a different approach to explore miRNA functions and their relationship with some cell phenotypes. For example, Sun and collaborators used human gastric organoids to elucidate the role of miR-324-3p in gastric cancer. The results showed that $\mathrm{miR}-324-3 \mathrm{p}$ is upregulated in GC tissues and cells, and it may act as an oncogene, improving cell proliferation, migration, and vitality. They also found that miR-324-3p targeted SMAD4, which has been described as a tumor suppressor in some cancers, including in GC. SMAD4 was shown to modulate cell process, such as proliferation, apoptosis, and migration. Finally, they suggested that miR-324-3p increased gastric organoid growth by activating Wnt/ $\beta$-catenin via downregulation of SMAD4. However, there is a lack of evidence to support this assertion [81]. Yuan et al. explored the role of miR-18a and miR-19a in GC, both derived from MIR17HG (MiR-17-92a-1 Cluster Host Gene), a class of pri-miRNAs located in human chromosome 13. The results suggested that miR-18a and miR19a promoted GC metastasis by targeting SMAD2 and upregulating Wnt/ $\beta$-catenin. Additionally, IRF-1 (a nuclear transcription regulator) could inhibit MIR17HG expression, showing a potential clinical advance for GC pathogenesis [83].

\subsection{Drug Resistance}

One of the most challenging tasks in GC treatment is to understand how some cells can resist the effect of chemotherapeutic treatments. For this reason, it is interesting to identify and elucidate drug resistance mechanisms of gastric cancer stem cells (GCSCs). In this topic, we will expose the studies involving the Wnt signaling pathway and miRNAs regulating the stemness properties of gastric cancer cell lines described in the literature. It is important to point out that, although some studies present evidence to support a direct relationship between the effects caused by miRNAs in the Wnt pathway and stemness phenotypes, most studies only present correlations between the studied miRNAs and phenotypic alterations associated with the Wnt pathway. Therefore, a careful look at the methodology used is necessary. Wu et al. explored the upregulated miR-483-5p in GCSC derived from MKN-45 gastric cancer cells. Using in vitro experiments, they showed that miR-483-5p can improve cell proliferation and decrease cell apoptosis in GCSCs compared to GC parental cells. Additionally, they showed that miR-483-5p upregulation activates expression of $\beta$ catenin, its downstream target molecules cyclin D1, and matrix metalloproteinase 2, while decreasing Bcl 2 expression [85]. An overview of the studies selected for this topic can be found in Table 4 . 
Table 4. MiRNAs associated with self-renewal phenotype and Wnt/ $\beta$-catenin pathway in gastric cancer.

\begin{tabular}{|c|c|c|c|c|c|c|c|c|}
\hline $\begin{array}{c}\text { Gene or Protein That } \\
\text { Targets miRNA }\end{array}$ & miRNAs & $\begin{array}{l}\text { Status } \\
\text { in GC }\end{array}$ & Targets & $\begin{array}{c}\text { Consequence on } \\
\text { Wnt } / \beta \text {-Catenin Pathway }\end{array}$ & $\begin{array}{c}\text { Sphere } \\
\text { Formation }\end{array}$ & Cell Lines Used & Study Type & Ref. \\
\hline Not elucidated & $\operatorname{miR}-483-5 p$ & $\uparrow$ & Not elucidated & Induction & $\uparrow$ & MKN-45 & In vitro & [85] \\
\hline SLC34A2 & $\operatorname{miR}-25$ & $\uparrow$ & GSK3 $\beta$ & Induction & $\uparrow$ & MKN-28 MKN-45 & $\begin{array}{l}\text { In vitro and } \\
\text { in vivo }\end{array}$ & [86] \\
\hline Not elucidated & $\operatorname{miR}-501-5 p$ & $\uparrow$ & $\begin{array}{l}\text { DKK1 NKD1 } \\
\text { GSK3 } \beta\end{array}$ & Induction & $\uparrow$ & $\begin{array}{c}\text { SGC-7901 HGC-27 } \\
\text { MGC-803 } \\
\text { MKN-28 } \\
\text { BGC-823 }\end{array}$ & In vitro & [87] \\
\hline$B R D 4$ & $\operatorname{miR}-216 a-3 p$ & $\downarrow$ & Wnt3a & Suppression & $\downarrow$ & $\begin{array}{c}\text { AGS, BGC-823 } \\
\text { MKN-45 MGC-803 } \\
\text { SGC-7901 GES-1 }\end{array}$ & In vitro & [88] \\
\hline
\end{tabular}

$\uparrow:$ Upregulation, $\downarrow$ : Downregulation.

\section{Long Non-Coding RNAs Associated with Wnt/ $\beta$-Catenin Signaling Pathway}

The hallmarks of cancer, proposed by Hanahan and Weinberg [89], identified a set of common tumor characteristics: self-sufficiency in growth signals, insensitivity to antigrowth signals, evading apoptosis, limitless replicative potential, sustained angiogenesis, and tissue invasion and metastasis. As aforementioned, lncRNAs were proposed as important players in many tumorigenesis processes, including cell proliferation, invasion, migration, angiogenesis, escaping apoptosis, and acquiring drug resistance. Most of the lncRNAs acting through the Wnt/ $\beta$-Catenin pathway in GC were reported to be associated with more than one of the hallmarks of cancer. As well as in the miRNA section, here, we will describe in more detail the noticeable Wnt/ $\beta$-catenin-related lncRNAs in GC. Table 5 will provide a summary of the other lncRNAs.

Table 5. LncRNAs aberrantly expressed in GC and associated with the Wnt/ $\beta$-catenin signaling pathway.

\begin{tabular}{|c|c|c|c|c|}
\hline lncRNA & Proposed Mechanism & Expression in GC & Cancer Related Phenotype & Ref. \\
\hline HOTAIR & ceRNA-miR34a & Upregulated & Drug Resistance & [90] \\
\hline CAT104 & ceRNA-miR-381 & Upregulated & Cell proliferation, migration, invasion, and apoptosis & {$[91]$} \\
\hline LINC01133 & ceRNA-miR-106a-3p & Downregulated & Cell proliferation, migration, and invasion & [92] \\
\hline LINC01606 & ceRNA-miR-423-5p & Upregulated & Cell migration and invasion & [93] \\
\hline LINC00052 & interacts with $\beta$-catenin and SMYD2 & Upregulated & Cell proliferation, migration, and invasion & {$[94]$} \\
\hline BCAR4 & Not elucidated & Upregulated & Drug resistance & [95] \\
\hline FEZF1-AS1 & Not elucidated & Upregulated & Cell proliferation & [96] \\
\hline MALAT1 & Not elucidated & Upregulated & Cell proliferation, migration, invasion, and apoptosis & [97] \\
\hline ENST00000434223 & Not elucidated & Downregulated & Cell proliferation, migration, invasion, and apoptosis & [98] \\
\hline lnc-GNAT1-1 & Not elucidated & Downregulated & Cell proliferation, migration, and invasion & [99] \\
\hline PEG10 & ceRNA-miR-3200 & Upregulated & Cell proliferation, migration, invasion, and apoptosis & [100] \\
\hline TP73-AS1 & Not elucidated & Upregulated & Cell proliferation and invasion & [101] \\
\hline LINC01225 & Not elucidated & Upregulated & Cell proliferation, migration, and invasion & {$[102]$} \\
\hline TOB1-AS1 & ceRNA-miR-23a & Upregulated & Cell proliferation, migration, invasion, and apoptosis & [103] \\
\hline ZFAS1 & ceRNA-miRNA-200b-3p & Upregulated & Cell proliferation, migration, invasion, and drug resistance & [104] \\
\hline MIR4435-2HG & Not elucidated & Upregulated & Cell proliferation, migration, invasion, and apoptosis & [105] \\
\hline LINC01314 & Not elucidated & Downregulated & Cell migration, invasion, and angiogenesis & {$[106]$} \\
\hline HCG11 & ceRNA-miR-1276 & Upregulated & Cell proliferation, migration, and apoptosis & {$[107]$} \\
\hline GATA6-AS1 & interaction with $\mathrm{EZH} 2$ & Downregulated & Cell proliferation, migration, and invasion & [108] \\
\hline GASL1 & Not elucidated & Downregulated & Cell proliferation & [109] \\
\hline LINC01503 & Not elucidated & Upregulated & Cell proliferation and invasion & [110] \\
\hline PCAT6 & ceRNA-miR-15a & Upregulated & Cell proliferation and apoptosis & [111] \\
\hline OIP5-AS1 & ceRNA-miR-367-3p & Upregulated & Cell proliferation and apoptosis & [112] \\
\hline NNT-AS1 & ceRNA-miR-142-5p & Upregulated & Cell proliferation, migration, invasion, and apoptosis & [113] \\
\hline HOXC-AS1 & interaction with eIF4A3 & Upregulated & Cell proliferation and apoptosis & [114] \\
\hline FAM83H-AS1 & Not elucidated & Upregulated & Drug resistance & [115] \\
\hline
\end{tabular}

\subsection{Cell Proliferation}

The most frequent tumoral phenotype associated with lncRNAs and the Wnt/ $\beta$ Catenin pathway is aberrant cell proliferation. For instance, CAT104 was initially reported as part of a lncRNA signature model along with LINC01234 (Long Intergenic Non-Protein Coding RNA 1234), and STXBP5-AS1 (Syntaxin Binding Protein 5 Antisense RNA 1) to predict breast cancer patient survival [116]. In 2018, CAT104 was shown to be an oncogenic lncRNA, as it is highly expressed in a panel of human GC cells when compared to normal cell lines. Successively, CAT104 repression decreased cell proliferation, invasion, and migration and promoted apoptosis. In silico and in vitro studies demonstrated that CAT104 acts as a ceRNA for miR-381. Additionally, miR-381 was necessary for CAT104 silencing described phenotypes in GC cells. The expression of Wnt/ $\beta$-catenin signaling-related proteins Wnt3a, Wnt5a, and $\beta$-catenin was decreased by miR-381 mimic transfection, while 
their expression was upregulated upon miR-381 inhibitor transfection. ZEB1, one of the genes transcriptionally regulated by $\beta$-catenin [117], was identified as a direct target of miR-381. ZEB1 overexpression was able to rescue the oncogenic phenotypes in GC cells caused by miR-381 upregulation. Conversely, ZEB1 knockdown reversed the miR-381 inhibitor effects, supporting the idea that the biological function of CAT104 was mediated by miR-381 and ZEB1 in GC cells [91].

LINC01133, previously described as an important lncRNA for cancer progression and metastasis [118,119], was reported to be downregulated in GC. Low expression of LINC01133 was associated with poor overall survival rates and progression-free survival, while patients with higher levels of LINC01133 showed the opposite trend, conferring to it a protective characteristic, and thus being considered a tumor suppressor lncRNA. LINC01133 overexpression inhibited proliferation, migration, and invasion in vitro and in vivo. In the same context, mesenchymal markers' vimentin and N-cadherin levels were reduced, whereas the epithelial marker E-cadherin levels were increased, indicating that EMT was inhibited. As a result of bioinformatics analysis and dual-luciferase reporter assays, miR-106a-3p was discovered to be a target of LINC01133. Analysis of differential gene expression, using miR-106a-3p depleted GC cells, identified APC (a tumor suppressor gene and component of the $\beta$-catenin destruction complex) as a target of miR-106a-3p. Rescue experiments supported this data and confirmed that LINC01133 is dependent on the miR-106a-3p/APC axis. Later, the Wnt signaling pathway was identified as the most enriched pathway after gene ontology analysis of publicly available miRNA target datasets, consistent with in vitro results of protein expression experiments of EMT-related genes [92].

\subsection{Cell Migration and Invasion}

Another important hallmark of tumor cells is their ability to migrate and invade distant sites to form metastasis. In this scenario, there are a few Wnt/ $\beta$-catenin-related lncRNAs that are responsible of regulating cellular migration and invasion.

The lncRNA ZFAS1 (Zinc finger nuclear transcription factor, X-box binding 1-type containing 1 antisense RNA 1 ) was reported as upregulated in GC and associated with the Wnt/ $\beta$-catenin. First, $\mathrm{Xu}$ et al. determined that ZFAS1 knockdown decreased cell proliferation, migration and invasion and drug resistance by regulating cyclin D1, cyclin E, cyclin B1, E-cadherin, N-cadherin, vimentin, MMP-2, and MMP-14. B-catenin mRNA and protein expression and GSK3 $\beta$ phosphorylation (Ser9) levels were declined, while NKD2 (NKD Inhibitor of Wnt Signaling Pathway 2) protein expression was increased after downregulation of ZFAS1. In addition, ZFAS1 silencing-induced malignancy inhibition was overturned $\beta$-catenin overexpression, which stimulated cell invasion and chemotherapy resistance, strongly revealing that ZFAS1 blocks the canonical Wnt/ $\beta$-catenin signaling pathway in GC to facilitate cell proliferation, migration, invasion, and drug resistance [120]. More recently, Zhang et al. confirmed that ZFAS1 induced the expression of phosphorylated GSK3 $\beta$ (p-GSK3 $\beta$ ) and $\beta$-catenin, besides Wnt1 upregulation. Beyond that, authors discovered that miR-200b was repressed in GC, and its overexpression led to reduced p-GSK3 $\beta$ and $\beta$-catenin expression. Consistently, ZFAS1 was found to directly target miR-200b, which, in turn, was shown to target Wnt1 directly. Farther, miR-200b upregulation counteracted the ZFAS1-induced cell proliferation, showing that ZFAS1 functions via miR-200b and through the Wnt/ $\beta$-catenin signaling pathway to increase cell proliferation in GC [104].

\subsection{Apoptosis}

As stated before, many lncRNAs acting through the Wnt/ $\beta$-Catenin pathway in GC were reported to be associated with more than one of the hallmarks of cancer.

Identified as highly expressed in a lncRNA microarray analysis, MIR4435-2 Host Gene (MIR4435-2HG) silencing inhibited cell proliferation, migration, and invasion while increasing apoptosis of GC cells. An RNA pull-down assay followed by mass spectrometry identified that MIR4435-2HG was a molecular decoy, being able to bind to DSP (Desmoplakin) and inhibit its expression. Moreover, increased E-cadherin expression and decreased 
expression levels of $\mathrm{N}$-cadherin, vimentin, c-myc, $\beta$-catenin, cyclin D1, and Survivin were observed in GC cells. After a series of rescue experiments and dual-luciferase reporter assays, MIR4435-2HG was found to activate the Wnt/ $\beta$-catenin signaling pathway through DSP to stimulate GC tumorigenesis [105].

OIP5 Antisense RNA 1 (OIP5-AS1) was found to be highly expressed in GC, and this upregulation is associated with shorter overall and disease-free survival rates of patients with GC. OIP5-AS1 overexpression and silencing showed that OIP5-AS1 induced cell proliferation and inhibited apoptosis in GC cells. Mechanistically, OIP5-AS1 was reported to be a molecular sponge for miR-367-3p, which, in turn, regulated the gene HMGA2 (High Mobility Group AT-Hook 2). Additionally, OIP5-AS1 was described to increase the p-AKT and $\mathrm{p}-\beta$-catenin levels, suggesting that OIP5-AS1 regulated the activation of AKT and $\beta$-catenin pathways through HMGA2 [112].

\subsection{Drug Resistance}

Another extensively studied mechanism of tumorigenesis is the ability of cells to resist treatment and become insensitive to anti-growth signals. One of the most studied oncogenic lncRNAs in cancer biology, HOTAIR (HOX transcript antisense RNA), was previously described as a ceRNA in GC [121-123].

More recently, HOTAIR was reported to be associated with Wnt/ $\beta$-catenin signaling. Cheng et al. found that HOTAIR was highly expressed in both GC patient samples, GC cell lines and cisplatin-resistant GC cell lines, while miR-34a was lowly expressed. Moreover, bioinformatics analysis followed by dual-luciferase reporter assays indicated that miR-34a was a target of HOTAIR. In addition, HOTAIR was shown to work via miR-34a to modulate cisplatin resistance and apoptosis by controlling the expression of the multidrug-resistance proteins ABCB1 (ATP Binding Cassette Subfamily B Member 1), ABCC1 (ATP Binding Cassette Subfamily C Member 1), and ABCG2 (ATP Binding Cassette Subfamily G Member 2), and apoptosis-related proteins cleaved caspase-3, Bax (BCL2 Associated X, Apoptosis Regulator), Bcl-2 (B-cell lymphoma 2), and Survivin. More interestingly, HOTAIR knockdown decreased the expression levels of Wnt1 and $\beta$-catenin in cisplatin-resistant GC cells. As expected, miR-34a overexpression rescued Wnt1 and $\beta$-catenin protein expression in HOTAIR silenced cells, confirming that HOTAIR regulates the Wnt/ $\beta$-catenin signaling pathways via miR-34a [90].

BCAR4 (Breast Cancer Anti-Estrogen Resistance 4 (Non-Protein Coding)) is upregulated and associated with worse patient outcomes in GC. Interestingly, BCAR4 expression was higher in diffuse GC tissue samples than in intestinal GC tissue samples, corroborating its association with more aggressive characteristics. Overexpression of BCAR4 increased cisplatin resistance, whereas silencing of BCAR4 increased sensitivity of cisplatin. Consistently, in cisplatin-resistant GC cells, BCAR4 was upregulated when compared to GC cells. Furthermore, in the context of tumor sphere formation experiments, BCAR4 increased the expression of $\beta$-catenin and the tumor stem cell biomarkers Nanog, Oct3/4, Sox2, c-myc, and Klf4. However, upregulation of these markers was abolished after $\beta$-catenin downregulation, indicating that BCAR4 promotes drug resistance by controlling $\beta$-catenin expression and its tumor stem cells' related genes [95].

\subsection{Angiogenesis}

Another cancer hallmark, angiogenesis was also reported to be involved in GC tumorigenesis via Wnt $/ \beta$-catenin. In order to discover differentially expressed lncRNAs, Tang et al. found LINC01314 (Long Intergenic Non-Protein Coding RNA 1314) to be reduced in GC. Further in silico pathway analysis and a dual-luciferase reporter assay identified that KLK4 (Kallikrein Related Peptidase 4) was a direct target of LINC01314 and it could regulate the Wnt/ $\beta$-catenin signaling pathway. In vitro LINC0134 overexpression downregulated KLK4, resulting in inhibited GC cell migration and invasion, and caused decreases in Wnt-1, $\beta$-catenin, cyclin D1, and N-cadherin and an increase in E-cadherin. Additional rescue experiments proved that KLK4 was essential for LINC01314 overex- 
pression changes in gene expression and phenotypes. In vitro and in vivo experiments evidenced that angiogenesis was also reduced after LINC0134 upregulation, which was corroborated by decreased expressions of VEGF-C (Vascular Endothelial Growth Factor C) and VEGFR3 (Vascular Endothelial Growth Factor Receptor 3) [106].

\section{Conclusions}

The early diagnosis of gastric cancer is decisive to increase the chances of cure without the need of mutilating surgery. By that, the study of new methods of early detection of GC are essential to decrease mortality rates and increase life quality and overall survival rates. In this work, we explore studies involving microRNAs and long-non-coding RNAs that affect the progression of gastric cancer through the Wnt/ $\beta$-catenin pathway.

The Wnt signaling is one of the most studied pathways in cancer cell physiology. In fact, there are numerous ncRNAs involved in promoting gastric cancer via this pathway.

Aside from the aberrant expression of the molecules directly involved in this pathway, here, we evidenced that many ncRNAs can also alter the expression of the Wnt signaling proteins, as well as the $\beta$-catenin-regulated genes promoting gastric carcinogenesis.

We observed that pathological changes can occur in several stages that make up the Wnt signaling pathway. In addition, they can include several classes of molecules, which may involve proteins, genes, microRNAs, and long non-coding RNAs in expression imbalance, both regulated for more and for less. In relation to drug resistance, it is necessary to obtain a better understanding of the characteristics of some cell subpopulations responsible for the maintenance of the tumor process and chemotherapy resistance, such as the phenotype of gastric cancer stem cells (GCSCs). As well, it is important to establish a characterization of this subpopulation aiming at improving the analysis for the next studies involving stem cells.

Regarding the cell lines used in the studies, is important to explore the heterogeneity of the tumorigenic process of gastric cancer in different populations, including cell lines that represent them. Some studies established and cytogenetically characterized gastric cancer cell lines from the population of northern Brazil [124-126]. Further studies are needed to produce articles with greater accuracy in the study of ncRNAs. Anauate and collaborators proposed miR-101-3p + miR-140-3p as the best choice for reference genes for RT-qPCR for a more accurate comparison analysis of miRNAs in gastric cancer tissues [127].

As we presented in this review, there are plentiful ncRNAs capable of using the Wnt/ $\beta$-catenin signaling pathway to modulate cell proliferation, invasion, apoptosis, migration, drug resistance, and metastatic spread of gastric cancer cells. This indicates that the Wnt/ $\beta$-catenin signaling pathway-related ncRNAs may be used not only as diagnostic and prognostic biomarkers but also as novel targets for GC therapy, increasing treatment efficacy and reducing side effects.

Author Contributions: Conceptualization, C.A.P. and M.A.C.S.; investigation, C.A.P. and B.T.R.K.; data curation, C.A.P. and B.T.R.K.; writing-original draft preparation, C.A.P. and B.T.R.K.; writingreview and editing, C.O.G., F.W. and M.A.C.S.; supervision, M.A.C.S. All authors have read and agreed to the published version of the manuscript.

Funding: This research was funded by Fundação de Amparo à Pesquisa do Estado de São Paulo (FAPESP), grant numbers 2016/25562-0, and 2019/20592-6; Conselho Nacional de Pesquisa (CNPq) grant number 2018/301127-2; and by Coordenação de Aperfeiçoamento de Pessoal de Nível Superior (CAPES) grant numbers 23038051640/2009-01, and 88882.430351/2019-01. M.A.C.S. was funded by Fundação de Amparo à Pesquisa do Estado de São Paulo (FAPESP) grant number 2016/25562-0; Conselho Nacional de Pesquisa (CNPq) grant number 2018/301127-2; and by Coordenação de Aperfeiçoamento de Pessoal de Nível Superior (CAPES) 23038051640/2009-01. B.T.R.K. was funded by Postdoctoral Fellowship, Fundação de Amparo à Pesquisa do Estado de São Paulo (FAPESP) 2019/20592-6. C.A.P. was funded by Coordenação de Aperfeiçoamento de Pessoal de Nível Superior (CAPES) Doctoral Fellowship 88882.430351/2019-01.

Acknowledgments: Figures were created with BioRender.com. 
Conflicts of Interest: The authors declare no conflict of interest.

\section{References}

1. Bray, F.; Ferlay, J.; Soerjomataram, I.; Siegel, R.L.; Torre, L.A.; Jemal, A. Cancer statistics 2018: Globocan estimates of incidence and mortality worldwide for 36 cancers in 185 countries. CA Cancer J. Clin. 2018, 68, 394-424. [CrossRef]

2. Group, H.C.C. Gastric cancer and Helicobacter pylori: A combined analysis of 12 case control studies nested within prospective cohorts. Gut 2001, 49, 347-353. [CrossRef]

3. Hino, R.; Uozaki, H.; Murakami, N.; Ushiku, T.; Shinozaki, A.; Ishikawa, S.; Morikawa, T.; Nakaya, T.; Sakatani, T.; Takada, K. Activation of DNA methyltransferase 1 by EBV latent membrane protein 2A leads to promoter hypermethylation of PTEN gene in gastric carcinoma. Cancer Res. 2009, 69, 2766-2774. [CrossRef] [PubMed]

4. Darling, A.L.; Abar, L.; Norat, T. WCRF-AICR continuous update project: Systematic literature review of prospective studies on circulating 25-hydroxyvitamin D and kidney cancer risk. J. Steroid Biochem. Mol. Biol. 2016, 164, 85-89. [CrossRef] [PubMed]

5. International Agency for Research on Cancer. A Review of Human Carcinogens: Personal Habits and Indoor Combustions; World Health Organization: Lyon, France, 2012; Volume 100.

6. Karimi, P.; Islami, F.; Anandasabapathy, S.; Freedman, N.D.; Kamangar, F. Gastric cancer: Descriptive epidemiology, risk factors, screening, and prevention. Cancer Epidemiol. Prev. Biomark. 2014, 23, 700-713. [CrossRef]

7. Mukaisho, K.-I.; Nakayama, T.; Hagiwara, T.; Hattori, T.; Sugihara, H. Two distinct etiologies of gastric cardia adenocarcinoma: Interactions among pH, Helicobacter pylori, and bile acids. Front. Microbiol. 2015, 6, 412. [CrossRef]

8. Lauren, P. The two histological main types of gastric carcinoma: Diffuse and so-called intestinal-type carcinoma: An attempt at a histo-clinical classification. J. Acta Pathol. Microbiol. Scand. 1965, 64, 31-49. [CrossRef]

9. Henson, D.E.; Dittus, C.; Younes, M.; Nguyen, H.; Albores-Saavedra, J. Differential trends in the intestinal and diffuse types of gastric carcinoma in the United States, 1973-2000: Increase in the signet ring cell type. Arch. Pathol. Lab. Med. 2004, 128, 765-770. [CrossRef] [PubMed]

10. Van der Woude, C.; Kleibeuker, J.; Tiebosch, A.; Homan, M.; Beuving, A.; Jansen, P.; Moshage, H. Diffuse and intestinal type gastric carcinomas differ in their expression of apoptosis related proteins. J. Pathol. 2003, 56, 699-702. [CrossRef]

11. Gigek, C.O.; Calcagno, D.Q.; Rasmussen, L.T.; Santos, L.C.; Leal, M.F.; Wisnieski, F.; Burbano, R.R.; Lourenco, L.G.; Lopes-Filho, G.J.; Smith, M.A.C. Genetic variants in gastric cancer: Risks and clinical implications. J. Exp. Mol. Pathol. 2017, 103, 101-111. [CrossRef]

12. Sánchez, Y.; Huarte, M. Long non-coding RNAs: Challenges for diagnosis and therapies. Nucleic Acid Ther. 2013, 23, 15-20. [CrossRef] [PubMed]

13. Ma, L.; Bajic, V.B.; Zhang, Z. On the classification of long non-coding RNAs. RNA Biol. 2013, 10, 924-933. [CrossRef]

14. Nature, E.P.C. An integrated encyclopedia of DNA elements in the human genome. Nature 2012, 489, 57-74. [CrossRef]

15. Chakraborty, M.; Chatterjee, A.; Krithika, S.; Vasulu, T. A Statistical Analysis of MicroRNA: Classification, Identification and Conservation Based on Structure and Function. In Growth Curve and Structural Equation Modeling; Springer International Publishing: Cham, Switzerland, 2015; pp. 223-258.

16. Mercer, T.R.; Dinger, M.E.; Sunkin, S.M.; Mehler, M.F.; Mattick, J.S. Specific expression of long noncoding RNAs in the mouse brain. Proc. Natl. Acad. Sci. USA 2008, 105, 716-721. [CrossRef]

17. Rinn, J.L.; Chang, H.Y. Genome regulation by long noncoding RNAs. Annu. Rev. Biochem. 2012, 81, 145-166. [CrossRef]

18. Choudhuri, S. Small noncoding RNAs: Biogenesis, function, and emerging significance in toxicology. J. Biochem. Mol. Toxicol 2010, 24, 195-216. [CrossRef]

19. Ponting, C.P.; Oliver, P.L.; Reik, W. Evolution and functions of long noncoding RNAs. Cell 2009, 136, 629-641. [CrossRef] [PubMed]

20. Derrien, T.; Johnson, R.; Bussotti, G.; Tanzer, A.; Djebali, S.; Tilgner, H.; Guernec, G.; Martin, D.; Merkel, A.; Knowles, D.G. The GENCODE v7 catalog of human long noncoding RNAs: Analysis of their gene structure, evolution, and expression. Genome Res. 2012, 22, 1775-1789. [CrossRef] [PubMed]

21. Negishi, M.; Wongpalee, S.P.; Sarkar, S.; Park, J.; Lee, K.Y.; Shibata, Y.; Reon, B.J.; Abounader, R.; Suzuki, Y.; Sugano, S. A new lncRNA, APTR, associates with and represses the CDKN1A/p21 promoter by recruiting polycomb proteins. PLoS ONE 2014, 9, e95216. [CrossRef]

22. Hung, T.; Wang, Y.; Lin, M.F.; Koegel, A.K.; Kotake, Y.; Grant, G.D.; Horlings, H.M.; Shah, N.; Umbricht, C.; Wang, P. Extensive and coordinated transcription of noncoding RNAs within cell-cycle promoters. Nat. Genet. 2011, 43, 621-629. [CrossRef]

23. Yin, G.; Tian, P.; BuHe, A.; Yan, W.; Li, T.; Sun, Z. LncRNA LINC00689 Promotes the Progression of Gastric Cancer Through Upregulation of ADAM9 by Sponging miR-526b-3p. Cancer Manag. Res. 2020, 12, 4227-4239. [CrossRef]

24. Kretz, M.; Siprashvili, Z.; Chu, C.; Webster, D.E.; Zehnder, A.; Qu, K.; Lee, C.S.; Flockhart, R.J.; Groff, A.F.; Chow, J. Control of somatic tissue differentiation by the long non-coding RNA TINCR. Nature 2013, 493, 231-235. [CrossRef]

25. Liu, B.; Sun, L.; Liu, Q.; Gong, C.; Yao, Y.; Lv, X.; Lin, L.; Yao, H.; Su, F.; Li, D. A cytoplasmic NF-kB interacting long noncoding RNA blocks IKB phosphorylation and suppresses breast cancer metastasis. Cancer Cell 2015, 27, 370-381. [CrossRef]

26. Fang, S.; Zhang, L.; Guo, J.; Niu, Y.; Wu, Y.; Li, H.; Zhao, L.; Li, X.; Teng, X.; Sun, X. NONCODEV5: A comprehensive annotation database for long non-coding RNAs. Nucleic Acids Res. 2018, 46, D308-D314. [CrossRef] [PubMed] 
27. Frankish, A.; Diekhans, M.; Ferreira, A.-M.; Johnson, R.; Jungreis, I.; Loveland, J.; Mudge, J.M.; Sisu, C.; Wright, J.; Armstrong, J. GENCODE reference annotation for the human and mouse genomes. Nucleic Acids Res. 2019, 47, D766-D773. [CrossRef]

28. Tsagakis, I.; Douka, K.; Birds, I.; Aspden, J.L. Long non-coding RNAs in development and disease: Conservation to mechanisms. J. Pathol. 2020, 250, 480-495. [CrossRef]

29. Bartel, D. MicroRNAs: Genomics, biogenesis, mechanism, and function. Cell 2004, 116, 281-297. [CrossRef]

30. Williams, A.E. Functional aspects of animal microRNAs. Cell Mol. Life Sci. 2008, 65, 545-562. [CrossRef] [PubMed]

31. Siomi, H.; Siomi, M.C. On the road to reading the RNA-interference code. Nature 2009, 457, 396-404. [CrossRef] [PubMed]

32. Lee, R.C.; Feinbaum, R.L.; Ambros, V. The C. elegans heterochronic gene lin-4 encodes small RNAs with antisense complementarity to lin-14. Cell 1993, 75, 843-854. [CrossRef]

33. Chen, Y.; Wang, X. miRDB: An online database for prediction of functional microRNA targets. Nucleic Acids Res. 2020, 48, D127-D131. [CrossRef]

34. Lee, Y.S.; Dutta, A. The tumor suppressor microRNA let-7 represses the HMGA2 oncogene. Genes Dev. 2007, 21, 1025-1030. [CrossRef]

35. Pereira, J.; Santos, M.; Delabio, R.; Barbosa, M.; Smith, M.; Payão, S.; Rasmussen, L. Analysis of Gene Expression of miRNA-106b-5p and TRAIL in the Apoptosis Pathway in Gastric Cancer. Genes 2020, 11, 393. [CrossRef] [PubMed]

36. Sharma, R.; Chopra, V. Effect of the Wingless (wg1) mutation on wing and haltere development in Drosophila melanogaster. Dev. Biol. 1976, 48, 461-465. [CrossRef]

37. Nüsslein-Volhard, C.; Wieschaus, E. Mutations affecting segment number and polarity in Drosophila. Nature 1980, $287,795$. [CrossRef] [PubMed]

38. Oates, N.A.; van Vliet, J.; Duffy, D.L.; Kroes, H.Y.; Martin, N.G.; Boomsma, D.I.; Campbell, M.; Coulthard, M.G.; Whitelaw, E.; Chong, S. Increased DNA methylation at the AXIN1 gene in a monozygotic twin from a pair discordant for a caudal duplication anomaly. Am. J. Hum. Genet. 2006, 79, 155-162. [CrossRef]

39. Kanazawa, A.; Tsukada, S.; Sekine, A.; Tsunoda, T.; Takahashi, A.; Kashiwagi, A.; Tanaka, Y.; Babazono, T.; Matsuda, M.; Kaku, K. Association of the gene encoding wingless-type mammary tumor virus integration-site family member 5B (WNT5B) with type 2 diabetes. Am. J. Hum. Genet. 2004, 75, 832-843. [CrossRef] [PubMed]

40. Clevers, H. Wnt/ $\beta$-catenin signaling in development and disease. Cell 2006, 127, 469-480. [CrossRef]

41. Veeman, M.T.; Axelrod, J.D.; Moon, R.T. A second canon: Functions and mechanisms of $\beta$-catenin-independent Wnt signaling. Dev. Cell 2003, 5, 367-377. [CrossRef]

42. Savagner, P. Leaving the neighborhood: Molecular mechanisms involved during epithelial-mesenchymal transition. Bioessays 2001, 23, 912-923. [CrossRef]

43. García-Castro, M.n.I.; Marcelle, C.; Bronner-Fraser, M. Ectodermal Wnt function as a neural crest inducer. Science 2002, 297, 848-851. [CrossRef] [PubMed]

44. Arwert, E.N.; Hoste, E.; Watt, F.M. Epithelial stem cells, wound healing and cancer. Nat. Rev. Cancer 2012, 12, 170-180. [CrossRef]

45. Gonzalez, D.M.; Medici, D. Signaling mechanisms of the epithelial-mesenchymal transition. Sci. Signal. 2014, 7, re8. [CrossRef]

46. Tammela, T.; Sanchez-Rivera, F.J.; Cetinbas, N.M.; Wu, K.; Joshi, N.S.; Helenius, K.; Park, Y.; Azimi, R.; Kerper, N.R.; Wesselhoeft, R.A. A Wnt-producing niche drives proliferative potential and progression in lung adenocarcinoma. Nature 2017, 545, 355-359. [CrossRef] [PubMed]

47. de Sousa e Melo, F.; Kurtova, A.V.; Harnoss, J.M.; Kljavin, N.; Hoeck, J.D.; Hung, J.; Anderson, J.E.; Storm, E.E.; Modrusan, Z.; Koeppen, H. A distinct role for Lgr5+ stem cells in primary and metastatic colon cancer. Nature 2017, 543, 676-680. [CrossRef] [PubMed]

48. Batlle, E.; Clevers, H. Cancer stem cells revisited. Nat. Med. 2017, 23, 1124. [CrossRef] [PubMed]

49. Koushyar, S.; Powell, A.G.; Vincan, E.; Phesse, T.J. Targeting Wnt Signaling for the Treatment of Gastric Cancer. Int. J. Mol. Sci. 2020, 21, 3927. [CrossRef] [PubMed]

50. Pan, K.-F.; Liu, W.-G.; Zhang, L.; You, W.-C.; Lu, Y.-Y. Mutations in components of the Wnt signaling pathway in gastric cancer. World J. Gastroenterol. 2008, 14, 1570. [CrossRef] [PubMed]

51. Ebert, M.P.A.; Fei, G.; Kahmann, S.; Müller, O.; Yu, J.; Sung, J.J.Y.; Malfertheiner, P. Increased beta-catenin mRNA levels and mutational alterations of the APC and beta-catenin gene are present in intestinal-type gastric cancer. Carcinogenesis 2002, 23, 87-91. [CrossRef]

52. Clements, W.M.; Wang, J.; Sarnaik, A.; Kim, O.J.; MacDonald, J.; Fenoglio-Preiser, C.; Groden, J.; Lowy, A.M. beta-Catenin mutation is a frequent cause of Wnt pathway activation in gastric cancer. Cancer Res. 2002, 62, 3503-3506.

53. Min, B.-H.; Hwang, J.; Kim, N.K.; Park, G.; Kang, S.Y.; Ahn, S.; Ahn, S.; Ha, S.Y.; Lee, Y.K.; Kushima, R.; et al. Dysregulated Wnt signalling and recurrent mutations of the tumour suppressor RNF43 in early gastric carcinogenesis. J. Pathol. 2016, 240, 304-314. [CrossRef]

54. Radulescu, S.; Ridgway, R.A.; Cordero, J.; Athineos, D.; Salgueiro, P.; Poulsom, R.; Neumann, J.; Jung, A.; Patel, S.; Woodgett, J.; et al. Acute WNT signalling activation perturbs differentiation within the adult stomach and rapidly leads to tumour formation. Oncogene 2013, 32, 2048-2057. [CrossRef] [PubMed]

55. Oshima, H.; Oshima, M. Mouse models of gastric tumors: Wnt activation and PGE2 induction. Pathol. Int. 2010, 60, 599-607. [CrossRef] 
56. Czyzewska, J.; Guzińska-Ustymowicz, K.; Ustymowicz, M.; Pryczynicz, A.; Kemona, A. The expression of E-cadherin-catenin complex in patients with advanced gastric cancer: Role in formation of metastasis. Folia Histochem. Cytobiol. 2010, $48,37-45$. [CrossRef]

57. Sereno, M.; Castro, J.D.; Cejas, P.; García-Cabezas, M.A.; Belda, C.; Casado, E.; Feliu, J.; Gómez, C.; López, M.; Barón, M.G. Expression profile as predictor of relapse after adjuvant treatment in gastric cancer. J. Gastrointest. Cancer 2012, 43, 181-189. [CrossRef] [PubMed]

58. Dongre, A.; Weinberg, R.A. New insights into the mechanisms of epithelial-mesenchymal transition and implications for cancer. Nat. Rev. Mol. Cell Biol. 2019, 20, 69-84. [CrossRef]

59. Wu, C.; Zhuang, Y.; Jiang, S.; Liu, S.; Zhou, J.; Wu, J.; Teng, Y.; Xia, B.; Wang, R.; Zou, X. Interaction between Wnt/ $\beta$-catenin pathway and microRNAs regulates epithelial-mesenchymal transition in gastric cancer. Int. J. Oncol. 2016, 48, 2236-2246. [CrossRef] [PubMed]

60. Zhang, Z.; Liu, S.; Shi, R.; Zhao, G. miR-27 promotes human gastric cancer cell metastasis by inducing epithelial-to-mesenchymal transition. Cancer Genet. 2011, 204, 486-491. [CrossRef] [PubMed]

61. Zhao, X.; He, L.; Li, T.; Lu, Y.; Miao, Y.; Liang, S.; Guo, H.; Bai, M.; Xie, H.; Luo, G. SRF expedites metastasis and modulates the epithelial to mesenchymal transition by regulating miR-199a-5p expression in human gastric cancer. Cell Death Differ. 2014, 21, 1900-1913. [CrossRef]

62. Peng, Y.; Zhang, X.; Ma, Q.; Yan, R.; Qin, Y.; Zhao, Y.; Cheng, Y.; Yang, M.; Wang, Q.; Feng, X. MiRNA-194 activates the Wnt/ $\beta$-catenin signaling pathway in gastric cancer by targeting the negative Wnt regulator, SUFU. Cancer Lett. 2017, 385, 117-127. [CrossRef]

63. Zhang, X.; Peng, Y.; Huang, Y.; Yang, M.; Yan, R.; Zhao, Y.; Cheng, Y.; Liu, X.; Deng, S.; Feng, X. SMG-1 inhibition by miR-192/-215 causes epithelial-mesenchymal transition in gastric carcinogenesis via activation of Wnt signaling. Cancer Med. 2018, 7, 146-156. [CrossRef]

64. Li, Y.; Yan, X.; Shi, J.; He, Y.; Xu, J.; Lin, L.; Chen, W.; Lin, X.; Lin, X. Aberrantly expressed miR-188-5p promotes gastric cancer metastasis by activating Wnt/ $\beta$-catenin signaling. BMC Cancer 2019, 19, 505. [CrossRef] [PubMed]

65. Liu, L.; Tian, Y.-C.; Mao, G.; Zhang, Y.-G.; Han, L. MiR-675 is frequently overexpressed in gastric cancer and enhances cell proliferation and invasion via targeting a potent anti-tumor gene PITX1. J. Cell. Signal. 2019, 62, 109352. [CrossRef] [PubMed]

66. Su, J.; Zhang, A.; Shi, Z.; Ma, F.; Pu, P.; Wang, T.; Zhang, J.; Kang, C.; Zhang, Q. MicroRNA-200a suppresses the Wnt/ $\beta$-catenin signaling pathway by interacting with $\beta$-catenin. Int. J. Oncol. 2012, 40, 1162-1170. [CrossRef]

67. Cong, N.; Du, P.; Zhang, A.; Shen, F.; Su, J.; Pu, P.; Wang, T.; Zjang, J.; Kang, C.; Zhang, Q. Downregulated microRNA-200a promotes EMT and tumor growth through the wnt/ $\beta$-catenin pathway by targeting the E-cadherin repressors ZEB1/ZEB2 in gastric adenocarcinoma. Oncol. Rep. 2013, 29, 1579-1587. [CrossRef]

68. Wang, L.; Yu, T.; Li, W.; Li, M.; Zuo, Q.; Zou, Q.; Xiao, B. The miR-29c-KIAA1199 axis regulates gastric cancer migration by binding with WBP11 and PTP4A3. Oncogene 2019, 38, 3134-3150. [CrossRef] [PubMed]

69. Fang, Z.; Zhong, M.; Wang, Y.; Yuan, X.; Guo, H.; Yao, Y.; Feng, M.; Chen, J.; Xiong, J.; Xiang, X. miR-381 and miR-489 suppress cell proliferation and invasion by targeting CUL4B via the Wnt/ $\beta$-catenin pathway in gastric cancer. Int. J. Oncol. 2019, 54, 733-743. [CrossRef]

70. Song, B.; Lin, H.; Dong, L.; Ma, J.; Jiang, Z. MicroRNA-338 inhibits proliferation, migration, and invasion of gastric cancer cells by the Wnt/ $\beta$-catenin signaling pathway. Eur. Rev. Med. Pharm. Sci. 2018, 22, 1290-1296. [CrossRef]

71. Guo, F.; Gao, Y.; Sui, G.; Jiao, D.; Sun, L.; Fu, Q.; Jin, C. miR-375-3p/YWHAZ/ $\beta$-catenin axis regulates migration, invasion, EMT in gastric cancer cells. J. Clin. Exp. Pharmacol. Physiol. 2019, 46, 144-152. [CrossRef]

72. Zheng, J.-J.; Que, Q.-Y.; Xu, H.-T.; Luo, D.-S.; Sun, Z.; Ni, J.-S.; Que, H.-F.; Ma, J.; Wu, D.; Shi, H. Hypoxia activates SOX5/Wnt/ $\beta$ catenin signaling by suppressing MiR-338-3p in gastric cancer. J. Technol. Cancer Res. Treat. 2020, 19, 1533033820905825. [CrossRef]

73. Lin, L.; Xiao, J.; Shi, L.; Chen, W.; Ge, Y.; Jiang, M.; Li, Z.; Fan, H.; Yang, L.; Xu, Z. STRA6 exerts oncogenic role in gastric tumorigenesis by acting as a crucial target of miR-873. J. Exp. Clin. Cancer Res. 2019, 38, 452. [CrossRef] [PubMed]

74. Wang, G.; Huang, Y.-X.; Zhang, R.; Hou, L.-D.; Liu, H.; Chen, X.-Y.; Zhu, J.-S.; Zhang, J. Toosendanin suppresses oncogenic phenotypes of human gastric carcinoma SGC-7901 cells partly via miR-200a-mediated downregulation of $\beta$-catenin pathway. Int. J. Oncol. 2017, 51, 1563-1573. [CrossRef] [PubMed]

75. Tang, H.; Kong, Y.; Guo, J.; Tang, Y.; Xie, X.; Yang, L.; Su, Q.; Xie, X. Diallyl disulfide suppresses proliferation and induces apoptosis in human gastric cancer through Wnt-1 signaling pathway by up-regulation of miR-200b and miR-22. Cancer Lett. 2013, 340, 72-81. [CrossRef] [PubMed]

76. $\mathrm{Xu}, \mathrm{K}$; Zhao, Y.-C. MEF2D/Wnt/ $\beta$-catenin pathway regulates the proliferation of gastric cancer cells and is regulated by microRNA-19. Tumor Biol. 2016, 37, 9059-9069. [CrossRef] [PubMed]

77. Geng, Y.; Lu, X.; Wu, X.; Xue, L.; Wang, X.; Xu, J. MicroRNA-27b suppresses Helicobacter pylori-induced gastric tumorigenesis through negatively regulating Frizzled7. Oncol. Rep. 2016, 35, 2441-2450. [CrossRef]

78. Fang, Z.; Zhang, L.; Liao, Q.; Wang, Y.; Yu, F.; Feng, M.; Xiang, X.; Xiong, J. Regulation of TRIM24 by miR-511 modulates cell proliferation in gastric cancer. J. Exp. Clin. Cancer Res. 2017, 36, 17. [CrossRef] [PubMed]

79. Qiu, F.; Xiong, J.-P.; Deng, J.; Xiang, X.-J. TRIM29 functions as an oncogene in gastric cancer and is regulated by miR-185. Int. J. Clin. Exp. Pathol. 2015, 8, 5053. [PubMed] 
80. Hu, S.; Zheng, Q.; Wu, H.; Wang, C.; Liu, T.; Zhou, W. miR-532 promoted gastric cancer migration and invasion by targeting NKD1. Life Sci. 2017, 177, 15-19. [CrossRef]

81. Sun, G.-L.; Li, Z.; Wang, W.-Z.; Chen, Z.; Zhang, L.; Li, Q.; Wei, S.; Li, B.-W.; Xu, J.-H.; Chen, L. miR-324-3p promotes gastric cancer development by activating Smad4-mediated Wnt/beta-catenin signaling pathway. J. Gastroenterol. 2018, 53, 725-739. [CrossRef] [PubMed]

82. Zhao, D.; Wu, Q. Effect of inhibition to Yes-related proteins-mediated Wnt/ $\beta$-catenin signaling pathway through miR-195-5p on apoptosis of gastric cancer cells. J. Eur. Rev. Med. Pharm. Sci. 2019, 23, 6486-6496. [CrossRef]

83. Yuan, J.; Tan, L.; Yin, Z.; Zhu, W.; Tao, K.; Wang, G.; Shi, W.; Gao, J. MIR17HG-miR-18a/19a axis, regulated by interferon regulatory factor-1, promotes gastric cancer metastasis via Wnt/ $\beta$-catenin signalling. Cell Death Dis. 2019, 10, 454. [CrossRef] [PubMed]

84. Xu, Z.; Yu, Z.; Tan, Q.; Wei, C.; Tang, Q.; Wang, L.; Hong, Y. MiR-876-5p regulates gastric cancer cell proliferation, apoptosis and migration through targeting WNT5A and MITF. Biosci. Rep. 2019, 39, BSR20190066. [CrossRef]

85. Wu, K.; Ma, L.; Zhu, J. miR-483-5p promotes growth, invasion and self-renewal of gastric cancer stem cells by Wnt/ $\beta$-catenin signaling. Mol. Med. Rep. 2016, 14, 3421-3428. [CrossRef] [PubMed]

86. Zhang, L.; Guo, X.; Zhang, L.; Yang, F.; Qin, L.; Zhang, D.; Qin, Y. SLC34A2 regulates miR-25-Gsk3 $\beta$ signaling pathway to affect tumor progression in gastric cancer stem cell-like cells. Mol. Carcinog. 2018, 57, 440-450. [CrossRef] [PubMed]

87. Fan, D.; Ren, B.; Yang, X.; Liu, J.; Zhang, Z. Upregulation of miR-501-5p activates the wnt/ $\beta$-catenin signaling pathway and enhances stem cell-like phenotype in gastric cancer. J. Exp. Clin. Cancer Res. 2016, 35, 177. [CrossRef]

88. Song, H.; Shi, L.; Xu, Y.; Xu, T.; Fan, R.; Cao, M.; Xu, W.; Song, J. BRD4 promotes the stemness of gastric cancer cells via attenuating miR-216a-3p-mediated inhibition of Wnt/ $\beta$-catenin signaling. Eur. J. Pharmacol. 2019, 852, 189-197. [CrossRef]

89. Hanahan, D.; Weinberg, R.A. The hallmarks of cancer. Cell 2000, 100, 57-70. [CrossRef]

90. Cheng, C.; Qin, Y.; Zhi, Q.; Wang, J.; Qin, C. Knockdown of long non-coding RNA HOTAIR inhibits cisplatin resistance of gastric cancer cells through inhibiting the PI3K/Akt and Wnt/ $\beta$-catenin signaling pathways by up-regulating miR-34a. Int. J. Biol. Macromol. 2018, 107, 2620-2629. [CrossRef]

91. Yuan, G.; Quan, J.; Dong, D.; Wang, Q. Long noncoding RNA CAT104 promotes cell viability, migration, and invasion in gastric carcinoma cells through activation of microrna-381-inhibiting zinc finger E-box-binding homeobox 1 (ZEB1) expression. Oncol. Res. 2018, 26, 1037-1046. [CrossRef] [PubMed]

92. Yang, X.-Z.; Cheng, T.-T.; He, Q.-J.; Lei, Z.-Y.; Chi, J.; Tang, Z.; Liao, Q.-X.; Zhang, H.; Zeng, L.-S.; Cui, S.-Z. LINC01133 as ceRNA inhibits gastric cancer progression by sponging miR-106a-3p to regulate APC expression and the Wnt/ $\beta$-catenin pathway. Mol. Cancer 2018, 17, 126. [CrossRef] [PubMed]

93. Luo, Y.; Tan, W.; Jia, W.; Liu, Z.; Ye, P.; Fu, Z.; Lu, F.; Xiang, W.; Tang, L.; Yao, L. The long non-coding RNA LINC01606 contributes to the metastasis and invasion of human gastric cancer and is associated with Wnt/ $\beta$-catenin signaling. J. Int. J. Biochem. Cell Biol. 2018, 103, 125-134. [CrossRef]

94. Shan, Y.; Ying, R.; Jia, Z.; Kong, W.; Wu, Y.; Zheng, S.; Jin, H. LINC00052 promotes gastric cancer cell proliferation and metastasis via activating the Wnt/ $\beta$-catenin signaling pathway. Oncol. Res. 2017, 25, 1589-1599. [CrossRef]

95. Wang, L.; Chunyan, Q.; Zhou, Y.; He, Q.; Ma, Y.; Ga, Y.; Wang, X. BCAR4 increase cisplatin resistance and predicted poor survival in gastric cancer patients. Eur. Rev. Med. Pharm. Sci. 2017, 21, 4064-4070.

96. Wu, X.; Zhang, P.; Zhu, H.; Li, S.; Chen, X.; Shi, L. Long noncoding RNA FEZF1-AS1 indicates a poor prognosis of gastric cancer and promotes tumorigenesis via activation of Wnt signaling pathway. Biomed. Pharm. 2017, 96, 1103-1108. [CrossRef]

97. Lee, N.K.; Lee, J.H.; Ivan, C.; Ling, H.; Zhang, X.; Park, C.H.; Calin, G.A.; Lee, S.K. MALAT1 promoted invasiveness of gastric adenocarcinoma. BMC Cancer 2017, 17, 46. [CrossRef]

98. Zhao, Y.-X.; Liu, J.-F.; Sun, W.-J.; Zeng, R.-F.; Li, T.; Ma, R.-M. Long non-coding RNA-ENST00000434223 suppresses tumor progression in gastric cancer cells through the Wnt/ $\beta$-catenin signaling pathway. Int. J. Biol. Macromol. 2018, 120, 491-501. [CrossRef] [PubMed]

99. Liu, L.; Shuai, T.; Li, B.; Zhu, L.; Li, X. Long non-coding RNA lnc-GNAT1-1 inhibits gastric cancer cell proliferation and invasion through the Wnt/ $\beta$-catenin pathway in Helicobacter pylori infection. Mol. Med. Rep. 2018, 18, 4009-4015. [CrossRef] [PubMed]

100. Wang, J.; Chu, X.; Zhang, D.; Kong, D. Knockdown of long non-coding RNA PEG10 inhibits growth, migration and invasion of gastric carcinoma cells by up-regulating miR-3200. Neoplasma 2018, 65, 769-778. [CrossRef] [PubMed]

101. Wang, Y.; Xiao, S.; Wang, B.; Li, Y.; Chen, Q. Knockdown of lncRNA TP73-AS1 inhibits gastric cancer cell proliferation and invasion via the WNT/ $\beta$-catenin signaling pathway. Oncol. Lett. 2018, 16, 3248-3254. [CrossRef]

102. Xu, Y.; Zhang, G.; Zou, C.; Qi, W.; Gong, Z.; Zhang, G.; Ma, G.; Zhang, W.; Jiang, P. Long non-coding RNA LINC01225 promotes proliferation, invasion and migration of gastric cancer via Wnt/ $\beta$-catenin signalling pathway. J. Cell. Mol. Med. 2019, 23, 7581-7591. [CrossRef]

103. Jiang, K.; Zhi, X.; Ma, Y.; Zhou, L. Long non-coding RNA TOB1-AS1 modulates cell proliferation, apoptosis, migration and invasion through miR-23a/NEU1 axis via Wnt/b-catenin pathway in gastric cancer. Eur. Rev. Med. Pharmacol. Sci. 2019, 23, 9890-9899. [CrossRef] [PubMed]

104. Zhang, F.; Li, Y.; Xu, W.; He, L.; Tan, Y.; Xu, H. Long non-coding RNA ZFAS1 regulates the malignant progression of gastric cancer via the microRNA-200b-3p/Wnt1 axis. Biosci. Biotechnol. Biochem. 2019, 83, 1289-1299. [CrossRef] [PubMed] 
105. Wang, H.; Wu, M.; Lu, Y.; He, K.; Cai, X.; Yu, X.; Lu, J.; Teng, L. LncRNA MIR4435-2HG targets desmoplakin and promotes growth and metastasis of gastric cancer by activating Wnt/ $\beta$-catenin signaling. Aging 2019, 11, 6657. [CrossRef]

106. Tang, L.; Wen, J.-B.; Wen, P.; Li, X.; Gong, M.; Li, Q. Long non-coding RNA LINC01314 represses cell migration, invasion, and angiogenesis in gastric cancer via the Wnt/ $\beta$-catenin signaling pathway by down-regulating KLK4. Cancer Cell Int. 2019, 19, 94. [CrossRef]

107. Zhang, H.; Huang, H.; Xu, X.; Wang, H.; Wang, J.; Yao, Z.; Xu, X.; Wu, Q.; Xu, F. LncRNA HCG11 promotes proliferation and migration in gastric cancer via targeting miR-1276/CTNNB1 and activating Wnt signaling pathway. Cancer Cell Int. 2019, 19, 350. [CrossRef]

108. Li, Z.-T.; Zhang, X.; Wang, D.-W.; Xu, J.; Kou, K.-J.; Wang, Z.-W.; Yong, G.; Liang, D.-S.; Sun, X.-Y. Overexpressed lncRNA GATA6-AS1 Inhibits LNM and EMT via FZD4 through the Wnt/ $\beta$-Catenin Signaling Pathway in GC. Mol. Ther. Nucleic Acids 2020, 19, 827-840. [CrossRef] [PubMed]

109. Peng, C.; Li, X.; Yu, Y.; Chen, J. LncRNA GASL1 inhibits tumor growth in gastric carcinoma by inactivating the Wnt/ $\beta$-catenin signaling pathway. Exp. Ther. Med. 2019, 17, 4039-4045. [CrossRef]

110. Ding, J.; Shi, F.; Xie, G.; Zhu, Y. Long Non-coding RNA LINC01503 Promotes Gastric Cancer Cell Proliferation and Invasion by Regulating Wnt Signaling. Dig. Dis. Sci. 2020, 66, 452-459. [CrossRef]

111. Dong, D.; Lun, Y.; Sun, B.; Sun, H.; Wang, Q.; Yuan, G.; Quan, J. Silencing of long non-coding RNA PCAT6 restrains gastric cancer cell proliferation and epithelial-mesenchymal transition by targeting microRNA-15a. Gen. Physiol. Biophys. 2020, 39, 1-12 [CrossRef]

112. Tao, Y.; Wan, X.; Fan, Q.; Wang, Y.; Sun, H.; Ma, L.; Sun, C.; Wu, Y. Long non-coding RNA OIP5-AS1 promotes the growth of gastric cancer through the miR-367-3p/HMGA2 axis. Dig. Liver Dis. 2020, 52, 773-779. [CrossRef]

113. Zhang, J.; Zhang, K.; Hou, Y. Long non-coding RNA NNT-AS1 knockdown represses the progression of gastric cancer via modulating the miR-142-5p/SOX4/Wnt/ $\beta$-catenin signaling pathway. Mol. Med. Rep. 2020, 22, 687-696. [CrossRef]

114. Zhou, C.; An, N.; Cao, C.; Wang, G. IncRNA HOXC-AS1 promotes gastric cancer via binding eIF4AIII by activating Wnt/ $\beta$-catenin signaling. J. Gene Med. 2020, 22, e3202. [CrossRef]

115. Wang, B.; Guan, G.; Zhao, D. Silence of FAM83H-AS1 promotes chemosensitivity of gastric cancer through Wnt/ $\beta$-catenin signaling pathway. Biomed. Pharmacother. 2020, 125, 109961. [CrossRef]

116. Guo, W.; Wang, Q.; Zhan, Y.; Chen, X.; Yu, Q.; Zhang, J.; Wang, Y.; Xu, X.-j.; Zhu, L. Transcriptome sequencing uncovers a three-long noncoding RNA signature in predicting breast cancer survival. Sci. Rep. 2016, 6, 27931. [CrossRef] [PubMed]

117. Lamouille, S.; Xu, J.; Derynck, R. Molecular mechanisms of epithelial-mesenchymal transition. Nat. Rev. Mol. Cell Biol. 2014, 15, 178-196. [CrossRef]

118. Zeng, H.-F.; Qiu, H.-Y.; Feng, F.-B. Long noncoding RNA LINC01133 functions as an miR-422a sponge to aggravate the tumorigenesis of human osteosarcoma. Oncol. Res. 2018, 26, 335-343. [CrossRef]

119. Zhang, J.; Zhu, N.; Chen, X. A novel long noncoding RNA LINC01133 is upregulated in lung squamous cell cancer and predicts survival. Tumor Biol. 2015, 36, 7465-7471. [CrossRef]

120. Xu, W.; He, L.; Li, Y.; Tan, Y.; Zhang, F.; Xu, H. Silencing of lncRNA ZFAS1 inhibits malignancies by blocking Wnt/ $\beta$-catenin signaling in gastric cancer cells. Biosci. Biotechnol. Biochem. 2018, 82, 456-465. [CrossRef] [PubMed]

121. Geng, Y.; Xie, S.; Li, Q.; Ma, J.; Wang, G. Large intervening non-coding RNA HOTAIR is associated with hepatocellular carcinoma progression. J. Int. Med. Res. 2011, 39, 2119-2128. [CrossRef] [PubMed]

122. Liu, X.-H.; Sun, M.; Nie, F.-Q.; Ge, Y.-B.; Zhang, E.-B.; Yin, D.-D.; Kong, R.; Xia, R.; Lu, K.-H.; Li, J.-H. Lnc RNA HOTAIR functions as a competing endogenous RNA to regulate HER2 expression by sponging miR-331-3p in gastric cancer. Mol. Cancer 2014, 13, 92. [CrossRef]

123. Zhao, W.; An, Y.; Liang, Y.; Xie, X. Role of HOTAIR long noncoding RNA in metastatic progression of lung cancer. Eur. Rev. Med. Pharm. Sci. 2014, 18, 1930-1936.

124. Leal, M.F.; do Nascimento, J.L.M.; da Silva, C.E.A.; Lamarão, M.F.V.; Calcagno, D.Q.; Khayat, A.S.; Assumpção, P.P.; Cabral, I.R.; Smith, M.d.A.C.; Burbano, R.R. Establishment and conventional cytogenetic characterization of three gastric cancer cell lines. Cancer Genet. Cytogenet. 2009, 195, 85-91. [CrossRef] [PubMed]

125. Lima, E.M.; Rissino, J.D.; Harada, M.L.; Assumpção, P.P.; Demachki, S.; Guimarães, A.C.; Casartelli, C.; Smith, M.d.A.C.; Burbano, R.R. Conventional cytogenetic characterization of a new cell line, ACP01, established from a primary human gastric tumor. J. Braz. J. Med. Biol. Res. 2004, 37, 1831-1838. [CrossRef] [PubMed]

126. Ribeiro, H.F.; Alcântara, D.; Matos, L.A.; Sousa, J.M.D.C.; Leal, M.F.; Smith, M.D.A.C.; Burbano, R.R.; Bahia, M.D.O. Cytogenetic characterization and evaluation of c-MYC gene amplification in PG100, a new Brazilian gastric cancer cell line. Braz. J. Med. Biol. Res. 2010, 43, 717-721. [CrossRef] [PubMed]

127. Anauate, A.C.; Leal, M.F.; Wisnieski, F.; Santos, L.C.; Gigek, C.O.; Chen, E.S.; Geraldis, J.C.; Calcagno, D.Q.; Assumpcao, P.P.; Demachki, S.; et al. Identification of suitable reference genes for miRNA expression normalization in gastric cancer. Gene 2017, 621, 59-68. [CrossRef] [PubMed] 